\title{
EVALUASI HASIL TANGKAPAN BEBERAPA KEGIATAN PENANGKAPAN IKAN DI SUNGAI BARITO, KALIMANTAN TENGAH DAN SELATAN
}

\author{
Agus Djoko Utomo*) dan Dadik Prasetiyo*
}

\begin{abstract}
ABSTRAK
Perairan umum Sungai Barito ditinjau dari segi perikanan mempunyai nilai ekonomis penting bagi masyarakat terutama sebagai tempat mata pencaharian nelayan, sehingga harus dijaga kelestariannya agar dapat dimanfaatkan secara berkesinambungan. Penelitian ini bertujuan untuk mendapatkan data selektivitas beberapa alat tangkap terhadap ukuran beberapa jenis ikan, parameter mortalitas beberapa jenis ikan, musim penangkapan, dan hasil tangkapan beberapa alat tangkap. Informasi tersebut diharapkan dapat memberikan masukkan untuk pengelolaan sumber daya perikanan di Sungai Barito. Penelitian dilakukan dengan menggunakan metode survei pada berbagai badan air Sungai Barito pada bulan Mei sampai dengan Desember 2003. 2 tipe lokasi penelitian dipilih; tipe pertama perairan yang banyak aktivitas penangkapan yaitu beberapa lokasi di Kecamatan Danau Panggang (Kalimantan Selatan) dan tipe kedua yaitu daerah Rantau Birit Kecamatan Jenemas (Kalimantan Tengah) yang kondisi ekologinya sudah rusak. Teknik pengambilan contoh ikan dilakukan dengan cara acak dan pencatatan yang dilakukan oleh responden. Data hasil tangkapan dibuat tabulasi data, selektivitas alat dibuat dalam grafik histogram. Parameter pertumbuhan dan mortalitas dianalisis dengan paket program FISAT II. Hasil tangkapan di Rantau Birit Kecamatan Jenemas (Kalimantan Tengah) menunjukkan hasil yang lebih rendah daripada di beberapa perairan Kecamatan Danau Panggang (Kalimantan Selatan) yang kondisi ekosistemnya relatif masih baik. Ditinjau dari segi selektivitas alat tangkap terhadap ukuran ikan alat tangkap hampang, selambau, mangumpe, dan beje membahayakan kelestarian sumber daya perikanan terutama untuk jenis ikan yang berukuran besar seperti baung dan haruan, karena ikan ukuran kecil yang belum sempat bereproduksi sudah tertangkap. Nilai laju penangkapan untuk ikan berukuran besar yaitu haruan dan baung cukup tinggi yaitu berturut-turut $E=0,71$ dan 0,57 . Sedangkan untuk jenis ikan yang berukuran kecil seperti sepat siam nilai laju penangkapannya masih rendah yaitu $\mathrm{E}=0,41$.
\end{abstract}

\section{ABSTRACT: Catch evaluation of some fishing activities at Barito River South and Centre Kalimantan. By: Agus Djoko Utomo and Dadik Prasetiyo}

Barito River have economics value in fisheries, many fishes are living there and it's habitats for fishing, so that ecosystem should be managed properly. The objectives of the study was to reach fishing gear selectivity of length, fishing mortality of some fishes, catches data and fishing season of some main fishing gears. The research was conducted by survey methods on Mei 2003 to December 2003. Two types of locatian were selected; the first location at Danau Panggang district (South Kalimantan) there are many fishing activities, and the secound location at Rantau Birit, Jenemas district (Central Kalimantan) that location have strongly changing ecosystem. Data were collected by sampling methods and distributed questioner blank sheets to fisherment. Catches and selectivity data were analised using data tabulation and histogram grafik, growth and mortality parameter were analised by FISAT II program. The result shawed that catches data at Rantau Birit, Jenemas distrik (Central Kalimantan) lower than some location at Danau Panggang distrik (South Kalimantan). Main fishing gear: hampang (barrier with traps chamber), selambau (filtering net), beje (seine with pond traps), mangumpe (seine with fish aggregating device) are not selectived gears for big fish such as baung (Mystus nemurus) and haruan (Channa striatus), that device caught young fish before doing reproduction. The explotation rate $(E)=0.71$ for baung (Mystus nemurus), $E=0.57$ for Haruan (Channa striatus) and $E=0.41$ for sepat siam (Trichogaster pectoralis).

KEYWORD: $\quad$ evaluation, fishing activity, exploitation rate, openwater

\section{PENDAHULUAN}

Sungai Barito salah satu sungai besar di Kalimantan, adalah contoh tipe perairan umum yang bila ditinjau dari sumber daya perikanan mempunyai nilai ekonomi yang penting yaitu dapat menunjang perekonomian masyarakat setempat. Penurunan potensi sumber daya perikanan biasanya disebabkan antara lain oleh kerusakan lingkungan, kegiatan penangkapan yang tidak ramah lingkungan dan kegiatan penangkapan yang berlebihan.
Kegiatan penangkapan di perairan umum biasanya lebih banyak dilakukan di perairan paparan banjiran, karena perairan tersebut merupakan perairan yang produktif, kaya bagi sumber daya perikanannya (Welcomme, 1979). Kegiatan penangkapan yang sudah dilarang pemerintah, namun kadang-kadang masih digunakan oleh masyarakat adalah penggunaan racun, bahan peledak dan stroom (electric fishing). Hal ini, disebabkan sulitnya pengawasan di perairan umum dan kurangnya kepedulian masyarakat akan kelestarian sumber daya perikanan. Jenis alat tangkap yang

Peneliti pada Balai Riset Perikanan Perairan Umum, Palembang 
berpotensi membahayakan kelestarian sumber daya perikanan antara lain adalah tuguk (filtering device), karena alat tangkap tersebut memotong jalur ruaya ikan atau udang yang akan melakukan pemijahan (Utomo, 2001). Mortalitas tertinggi di paparan banjiran terjadi saat musim kemarau, karena perairan mengalami kekeringan dan aktivitas penangkapan meningkat. Arifin (1978); Hoggarth \& Utomo (1994) menyatakan jenis alat tangkap ukuran besar yang beroperasi saat kemarau yaitu ngesar (active seines net) dan ngesek (active barriers).

Kegiatan penangkapan di Sungai Barito yang dapat menangkap ikan dalam jumlah banyak, berbagai macam jenis ikan dan ukuran adalah hampang (barrier with traps chamber), selambau (filtering net), mangumpe (seine with fish aggregating device), dan beje (seine with pond traps). Jenis ikan yang sudah langka sulit ditemukan lagi yaitu belantau (Macrochirichthys macrohinus) dan tengkeloso (Scleropages formosus). Jenis ikan ikan yang jumlahnya menurun tajam yaitu tabirin (Wallago dinema), pipih (Notopterus chitala), bakut (Oxyeleotris marmorata), toman (Channa micropeltes), tapa (Wallago leeri), dan jelawat (Leptobarbus hoeveni). Secara umum, hasil tangkapan nelayan pada kurun waktu 10 terakhir mengalami penurunan (Utomo, et al., 2003)

Penelitian ini bertujuan untuk mendapatkan informasi tentang spesifikasi alat tangkap, cara operasi alat tangkap, selektivitas alat tangkap dari beberapa alat tangkap yang diduga membahayakan kelestarian perikanan yaitu hampang (barrier traps), selambau (filtering net), mangumpe (seine with fish aggregating device), dan beje (pond traps). Di samping itu juga parameter mortalitas beberapa jenis ikan yang sering tertangkap yaitu baung (Mystus nemurus), haruan (Channa striatus), dan sepat siam (Trichogaster pectoralis). Informasi tersebut diharapkan dapat memberikan masukan atau dukungan peraturan kegiatan penangkapan ikan di perairan Sungai Barito.

\section{BAHAN DAN METODE}

\section{Pengumpulan Data}

Penelitian dilakukan pada bulan Mei 2003 sampai dengan Desember 2003 di Sungai Barito, Kalimantan Tengah dan Selatan. Parameter yang diamati meliputi spesifiksi alat tangkap ikan, data tangkapan dari nelayan, komposisi jenis ikan menurut jenis alat tangkap, selektivitas alat terhadap jenis dan ukuran ikan, parameter mortalitas penangkapan beberapa jenis ikan. Pelaksanaan penelitian di lapangan dilakukan mewakili musim hujan dan kemarau yaitu pada bulan Mei, Agustus, Nopember, dan Desember 2003. Alat tangkap yang dijadikan sasaran penelitian yaitu hampang (barrier with traps chamber), selambau (Filtering net), beje (seine with pond traps), dan mangumpe (seine with fish aggregating device) karena alat tangkap tersebut dapat menangkap ikan dalam jumlah banyak dan tidak selektif. Lokasi penelitian yang dipilih adalah beberapa daerah di Kecamatan Danau Panggang (Kalimantan Selatan) yang banyak aktivitas penangkapan yaitu Paminggir, Sapala, Pal Batu, dan Danau Panggang; daerah tersebut mendapat air dari Sungai Sambujur (anak DAS Marito) yang kondisi ekosistemnya masih baik. Lokasi lain yang di pilih adalah Rantau Birit Kecamatan Jenemas (Kalimantan tengah) yang kondisi ekosistemnya sudah banyak yang rusak karena pembukaan lahan gambut sejuta hektar; daerah tersebut mendapat air dari Sungai Mangkatip (anak DAS Barito) (Gambar 1).

Alat tangkap pada saat beroperasi dipotret, kemudian kontruksi dan cara operasinya digambar dengan bantuan informasi dari nelayan, sehingga pada gambar kelihatan jelas bagaimana mekanismenya ikan tertangkap. Alat tersebut dicatat nama lokalnya dan nama ilmiahnya berdasarkan pada klasifikasi alat tangkap ikan menurut Brandt (1972); Welcomme (1979).

Data hasil tangkapan didapatkan dari hasil tangkapan yang dicatat oleh nelayan dengan bantuan borang isian yang dibagikan kepada nelayan. Untuk mengetahui komposisi hasil tangkapan dan ukuran ikan yang tertangkap, dilakukan pengambilan contoh ikan secara acak pada beberapa alat tangkap yaitu alat tangkap yang menjadi taget dalam penelitian (beje, mangumpai, selambau, dan hampang) yang diduga tidak selektif dan membahayakan kelestarian sumber daya ikan.

Beberapa jenis ikan yang menjadi target utama dalam evaluasi tingkat mortalitas yaitu kelompok ikan rawa (black fish) meliputi haruan (Channa striatus) dan sepat siam (Trichogaster pectoralis), sedangkan kelompok ikan sungai yaitu ikan baung (Mystus nemurus). Data frekuensi ukuran ikan tiap bulan didapatkan dari enumerator dilapangan yang telah dilatih sebelumnya tentang cara pengukuran ikan. Cara pengambilan contoh ukuran ikan adalah hasil tangkapan diambil sebagian secara acak dengan alat cerok, selanjutnya ikan tersebut diukur panjang totalnya $(\mathrm{cm})$. Cara pengambilan contoh ukuran ikan ini dilakukan pada alat tangkap yang menjadi target (Hampang, Selambau, Beje, Mangumpe) dan pada ikan yang menjadi target (Haruan, Sepat dan Baung).

\section{Analisis Data}

Jenis alat tangkap diambil potretnya, digambar cara operasi penangkapan dan mekanisme tertangkapnya ikan, akan dapat dipakai petunjuk awal apakah alat tersebut membahayakan kelestarian sumber daya perikanan. Hasil tangkapan, selektivitas alat terhadap jenis dan ukuran dibuat tabulasi data dan grafik histogram sehingga kelihatan alat mana yang tidak selektif. 


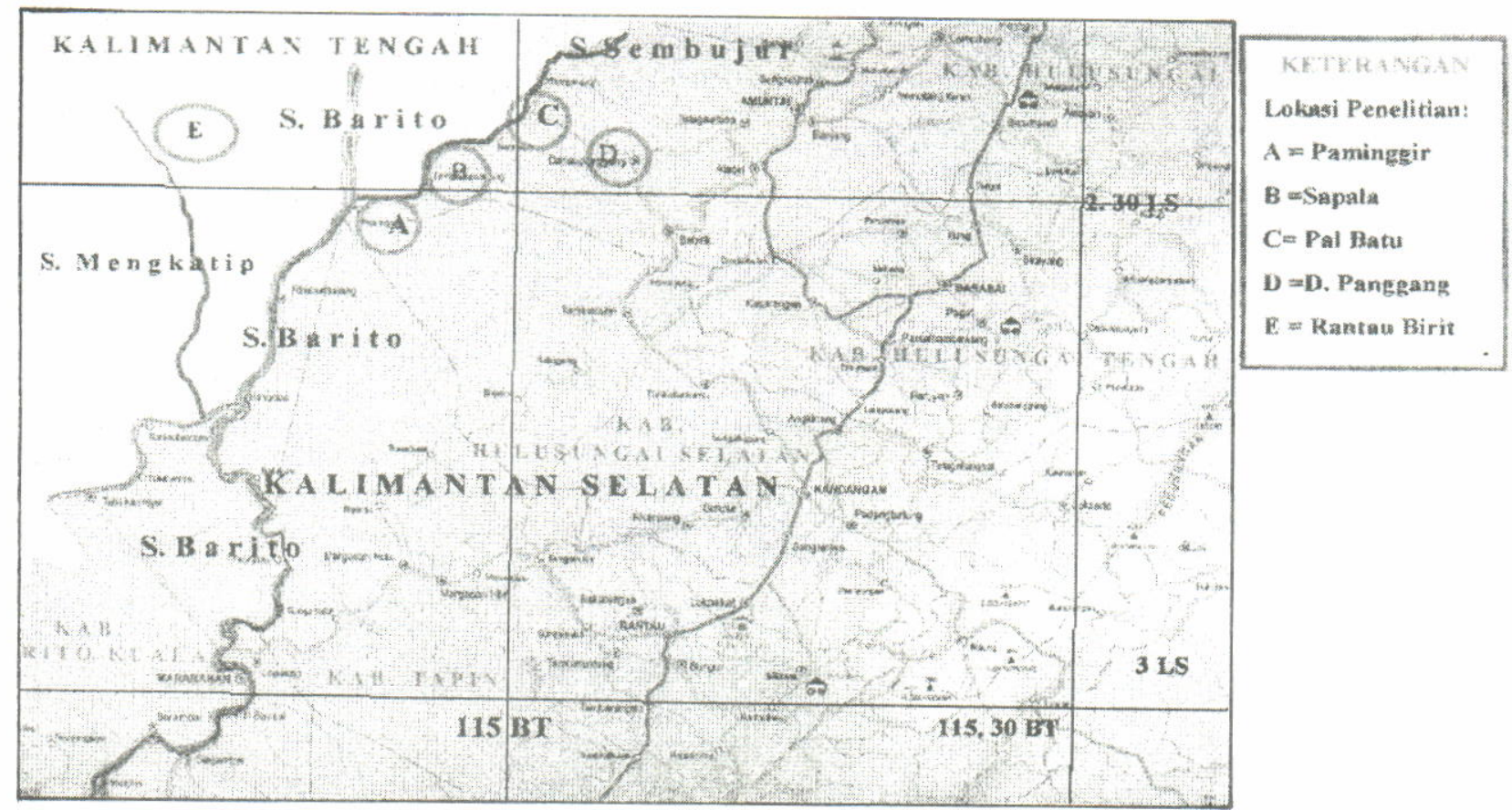

Gambar1

Figure 1.

Peta lokasi penelitian di DAS Kalimantan Selatan dan Kalimantan Tengah.

The map of research station in DAS Barito, South Kalimantan and Centre Kalimantan.

Parameter pertumbuhan individu ikan yaitu panjang infinitif $\left(L_{x}\right)$ dan koefisien percepatan pertumbuhan $(K)$ beberapa jenis ikan (sepat siam, haruan, dan baung), diduga berdasarkan pada data contoh frekuensi ukuran panjang yang di dapat dari bulan ke bulan dengan bantuan program ELEFAN dalam paket program FISAT II (Gayanilo et al., 1996). Parameter mortalitas penangkapan total (Z) diduga dengan metode Jones \& Van Zalinge dalam Spare \& Venema (1992) yang berdasarkan pada basis kelompok ukuran panjang dan parameter pertumbuhan yang telah didapatkan, dikerjakan dengan bantuan paket program FISAT II. Metode tersebut menggunakan persamaan regresi sebagai berikut:

$$
\log C\left\{\left(L, L_{x}\right)\right\}=a+Z / K^{*} \log \left(L_{x}-L\right)
$$

di mana:

$$
\mathrm{Z} / \mathrm{K}=\mathrm{b} \text { (sudut regresi) }
$$

\section{Keterangan:}

1. $C\left(L, L_{\infty}\right)=$ Hasil tangkapan kumulatif pada ukuran panjang $\mathrm{L} \mathrm{cm}$;

2. Lo=panjang infiniti, $K=k$ konstanta percepatan pertumbuhan, $Z=$ parameter mortalitas total.

Pendugaan parameter mortalitas alami (M) berdasarkan pada persamaan empiris Pauly, (1984) yaitu $\log (M)=-0,0152-0,2790 \log \left(L_{x}\right)+0,6543 \log$ $(K)+0,4634 \log (T)$, rata rata suhu perairan pada lokasi penelitian $28^{\circ} \mathrm{C}$. Sedangkan parameter mortalitas penangkapan $(F)=Z-M$ dan laju penangkapan $E=F / Z$.

\section{HASIL DAN BAHASAN}

\section{Deskripsi dan Cara Operasi Alat}

Alat tangkap selambau, hampang, mangumpe, dan beje (Gambar 2-5) banyak dijumpai di perairan rawa banjiran. Musim penangkapan dengan alat tangkap hampang dan selambau terjadi pada saat akhir musim penghujan (April-Juni), untuk menghadang ikan yang beruaya dari rawa (lebak) menuju ke sungai atau danau. Pada akhir musim penghujan, air mulai surut menuju bagian yang lebih dalam yaitu sungai, danau, dan lebung.

Alat tangkap mangumpe dan beje pada umumnya dioperasikan pada musim kemarau (Juli-September). Pada saat musim kemarau hanya badan air yang dalam yang berisi air yaitu sungai, danau, dan lebung. Alat tangkap beje untuk menangkap ikan yang berada di lebung (beje), sedangkan alat tangkap mangumpe untuk menangkap ikan di perairan sungai atau danau. Spesifikasi, cara operasi alat, dan ikan yang tertangkap dapat di lihat pada Tabel 1.

Nama lokal dan nama ilmiah ikan yang tertangkap (Local name and scientifics name of fish caught): baung (Mystus nemurus), tapa (Wallago leeri), lais (Cryptopterus spp.), puhing (Osteochilus sp.), gandaria (Dangila sp.), seluang (Rasbora spp.), sanggiringan (Mystus negriceps), sepat (Trichogaster spp.), haruan (Channa striata), biawan (Helostoma temminckii), jelawat (Leptobarbus haoveni), bantak (Dangila festiva), tabirin (Wallago denima), papuyu (Anabas testudineus), dan toman (Channa micropeltes). 
Tabel 1. Spesifikasi alat tangkap, cara penangkapan, dan ikan yang tertangkap

Table1. Gear spesifiction, its fishing methods and fish caught

\begin{tabular}{|c|c|c|c|}
\hline $\begin{array}{c}\text { Alat tang } \\
\text { kap (Fishing } \\
\text { gear) }\end{array}$ & 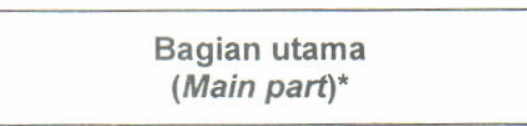 & $\begin{array}{l}\text { Cara penangkapan } \\
\text { (Fishing methods) }\end{array}$ & $\begin{array}{l}\text { Ikan utama ter } \\
\text { tangkap (Main } \\
\text { fish caught) }\end{array}$ \\
\hline $\begin{array}{l}\text { 1. Hampang } \\
\text { (Barrier with } \\
\text { traps cham } \\
\text { ber) } \\
\text { Gambar lihat } \\
\text { Lampiran } 2 \text {. } \\
\text { Jumlah } \\
\text { nelayan } \\
\text { utama } 2-3 \\
\text { orang, } \\
\text { nelayan } \\
\text { tambahan } \\
\text { saat musim } \\
\text { penangkapan } \\
3 \text { orang. }\end{array}$ & $\begin{array}{l}\text { 1. Hampang (sayap) } \\
\text { Anyaman bambu dengan jarak 1- } \\
2,5 \mathrm{~cm} \text {,tinggi } 1-2 \mathrm{~m} \text {, panjang } 50- \\
200 \mathrm{~m} \text {. } \\
\text { 2. Tukung } \\
\text { Perangkap ikan dari anyaman } \\
\text { bambu, panjang } 10-20 \mathrm{~m} \text {. } \\
\text { 3. Bulu mata (injab) } \\
\text { Tempat masuk ikan ke dalam } \\
\text { tukung, berbentuk hurup } \mathrm{V} \text {. }\end{array}$ & $\begin{array}{l}\text { Hampang sebagai alat utuk } \\
\text { menghadang dan mengarahkan } \\
\text { ikan masuk ke dalam perangkap } \\
\text { ikan (tukung) melewati injab (bulu } \\
\text { mata) yang berbentuk hurup } V \\
\text { sehingga ikan yang masuk sulit } \\
\text { keluar kembali. Alat ini diopersikan } \\
\text { pada perbatasan sungai utama dan } \\
\text { rawa (lebak), saat ikan beruaya dari } \\
\text { rawa ke sungai dan sebaliknya. } \\
\text { Musim penangkapan dilakukan } \\
\text { pada akhir musim hujan (April-Juni) } \\
\text { dan awal penghujan (Nopember). }\end{array}$ & $\begin{array}{l}\text { Lais, baung, } \\
\text { bantak puhing, } \\
\text { gandarium, } \\
\text { seluang, biawan, } \\
\text { sepat, gabus, } \\
\text { papuyu. }\end{array}$ \\
\hline $\begin{array}{l}\text { 2. Salambau } \\
\text { (Filtering } \\
\text { Net) } \\
\text { Gambar lihat } \\
\text { Lampiran } 3 . \\
\text { Jumlah } \\
\text { nelayan } \\
\text { utama } \\
\text { orang, } \\
\text { nelayan } \\
\text { tambahan } \\
\text { saat musim } \\
\text { penangkapan } \\
\text { 3-4 orang. }\end{array}$ & $\begin{array}{l}\text { 1. Selambau } \\
\text { Terbuat dari bahan waring, } \\
\text { berbentuk kerucut. Panjang } 40 \mathrm{~m} \text {, } \\
\text { diameter kerucut } 4 \mathrm{~m} \text {, mesh-size } \\
\text { bagian kantong } 1-2 \mathrm{~cm} \text {. } \\
\text { 2. Sawer (sayap) } \\
\text { Terbuat dari pagar anyaman } \\
\text { bambu, jarak anyaman 1-2,5 cm. } \\
\text { Panjang 10-0 m (selbar anak } \\
\text { sungai tempat pemasangan), } \\
\text { tinggi } 2-3 \mathrm{~m} \text {. } \\
\text { 3. Sesudak } \\
\text { Jalan masuk ikan ke dalam } \\
\text { selambau. Berbentuk hurup V. }\end{array}$ & $\begin{array}{l}\text { Dipasang memotong anak sungai } \\
\text { atau kanal. Sawer atau sayap } \\
\text { sebagai penghadang ikan agar } \\
\text { terarah masuk ke selambau. } \\
\text { Sesudak tempat jalan masuk ikan } \\
\text { ke dalam selambau, berbentuk } \\
\text { hurup V agar ikan yang masuk sulit } \\
\text { keluar kembali. } \\
\text { penangkapan pada akhir musim } \\
\text { hujan (April-Juni) dan awal } \\
\text { penghujan (Nopember). }\end{array}$ & $\begin{array}{l}\text { Patin, tapah, } \\
\text { baung, lais, } \\
\text { sanggiringan, } \\
\text { tabirin, seluang, } \\
\text { puhing, gandaria. }\end{array}$ \\
\hline $\begin{array}{l}\text { 3.Beje } \\
\text { (Seine with } \\
\text { pond traps) } \\
\text { Gambar lihat } \\
\text { Lampiran } 4 \text {. } \\
\text { Jumlah } \\
\text { nelayan } \\
\text { utama } 1-2 \\
\text { orang, } \\
\text { nelayan } \\
\text { tambahan } \\
\text { saat musim } \\
\text { penangkapan } \\
2-3 \quad \text { orang, } \\
\text { pada uda } \\
\text { umumnya } \\
\text { mempunyai } \\
\text { B-4 buah } \\
\text { Beje. }\end{array}$ & $\begin{array}{l}\text { 1.Galian tanah } \\
\text { Bentuk seperti kolam dengan } \\
\text { ukuran panjang 20-50 m dan } \\
\text { lebar 5-20 m. Di kiri-kanan kolam } \\
\text { dibuat saluran kecil ukuran lebar } \\
1 \mathrm{~m} \text { dalam } 0,5 \mathrm{~m} \text { dan panjang } 20- \\
50 \mathrm{~m} \text { yang dihubungkan dengan } \\
\text { kolam. Panjang kolam dan } \\
\text { saluran kolam dibuat searah } \\
\text { dengan sungai atau menghadang } \\
\text { pergerakkan air saat surut. Beje } \\
\text { dibangun di rawa dangkal di kiri } \\
\text { kanan sungai utama dan anak } \\
\text { sungai. } \\
\text { 2.Rempa } \\
\text { Bentuk seperti hapa (kelambu), } \\
\text { ukuran lebih kecil atau sama } \\
\text { dengan ukuran beje, terbuat dari } \\
\text { waring (nilon), mesh size nilon } \\
\text { 1,5-2,5 cm. }\end{array}$ & $\begin{array}{l}\text { Saat air mulai surut (kemarau) jenis } \\
\text { ikan rawa akan mencari tempat } \\
\text { yang dalam, antara lain beje. } \\
\text { Salurannya berfungsi untuk } \\
\text { mengarahkan ikan agar masuk ke } \\
\text { dalam beje (kolam). Rempa beje } \\
\text { (berbentuk hapa) dipasang dalam } \\
\text { kolam, keliling tepian kolam dan tali } \\
\text { ris rempa diberi jarak 20-30 cm } \\
\text { untuk jalan ikan masuk ke dalam } \\
\text { rempa. Ikan rawa adalah jenis ikan } \\
\text { yang mempunyai alat pernapasan } \\
\text { tambahan (labirinth), berusaha } \\
\text { mencari oksigen di permukaan air } \\
\text { dengan cara loncat ke permukaan } \\
\text { (tilap), saat itu akan terperangkap } \\
\text { masuk ke dalam rempa. Musim } \\
\text { penangkapan saat kemarau (Juli- } \\
\text { September) }\end{array}$ & $\begin{array}{l}\text { Jenis ikan rawa } \\
\text { (black fish) } \\
\text { terutama ikan } \\
\text { papuyuh, biawan, } \\
\text { gabus, sepat. }\end{array}$ \\
\hline
\end{tabular}


Tabel $1 . \quad$ Lanjutan

Table 1 . Continue

\begin{tabular}{|c|c|c|c|}
\hline $\begin{array}{c}\text { Alat tang } \\
\text { Kap (Fishing } \\
\text { gear) }\end{array}$ & $\begin{array}{l}\text { Bagian utama } \\
\text { (Main Part)* }\end{array}$ & $\begin{array}{l}\text { Cara penangkapan } \\
\text { (Fishing methods) }\end{array}$ & $\begin{array}{l}\text { Ikan utama ter } \\
\text { tangkap (Main } \\
\text { fish caught) }\end{array}$ \\
\hline $\begin{array}{l}\text { 4. Magumpe } \\
\text { (Seine with } \\
\text { Fish Agre } \\
\text { gating } \\
\text { Device) } \\
\text { Gambar lihat } \\
\text { Lampiran } 5 \\
\text { Jumlah } \\
\text { nelayan } \\
\text { utama } 2-3 \\
\text { orang, } \\
\text { nelayan } \\
\text { tambahan } \\
\text { saat musim } \\
\text { penangkapan } \\
3-4 \text { orang }\end{array}$ & $\begin{array}{l}\text { 1.Rumpon } \\
\text { Sebagai tempat pengumpul ikan } \\
\text { dibuat dari ranting kayu dan } \\
\text { tanamam air mengapung, dengan } \\
\text { posisi memanjang sejajar sungai, } \\
\text { ukuran } 30-50 \text { m dan lebar } 5-7 \mathrm{~m} \text {. } \\
\text { 2. Rempa (waring) } \\
\text { Alat ini dipasang mengelilingi } \\
\text { rumpon, mesh size } 1,5-2,5 \mathrm{~cm} \text {. }\end{array}$ & $\begin{array}{l}\text { Apabila ikan diperkirakan sudah } \\
\text { banyak terkumpul di rumpon, } \\
\text { keliling rumpon ditutup dengan } \\
\text { hampang bambu atau waring net. } \\
\text { Ranting kayu dan tanaman air } \\
\text { dibersihkan, hampang bambu atau } \\
\text { waring net digeser ke arah dalam } \\
\text { untuk memperkecil lahan dan } \\
\text { memudahkan penangkapan. } \\
\text { Dioperasikan pada pinggiran sungai } \\
\text { utama dan anak sungai. Musim } \\
\text { penangkapan saat kemarau (Juli- } \\
\text { September). }\end{array}$ & $\begin{array}{l}\text { Lais, jelawat, } \\
\text { tapah, baung, } \\
\text { puhing, gandaria, } \\
\text { seluang, haruan, } \\
\text { papuyu, sepat, } \\
\text { toman, biawan. }\end{array}$ \\
\hline
\end{tabular}

Catatan Tabel 1 (note of Table 1):

\section{Hasil Tangkapan dan Komposisi Jenis Ikan}

\section{a. Hasil tangkapan.}

Hasil tangkapan alat tangkap selambau mencapai puncaknya pada bulan Mei-Juni. Lokasi Rantau Birit yang kondisi ekosistemnya sudah rusak musim penangkapan lebih pendek yaitu pada bulan Mei, hasil tangkapannya juga tidak banyak (250 kg per hari). Pada lokasi di Pal Batu yang kondisi ekosistemnya masih baik musim penangkapannya lebih panjang yaitu bulan Mei dan Juni, hasil tangkapannya lebih tinggi (475-750 kg per hari), musim penangkapan dengan hasil yang hanya berlangsung kurang lebih 2 minggu. Lokasi Pal Batu banyak terdapat hutan rawa sebagai tempat pemijahan, mencari makan, dan tempat bernaung bagi anak ikan (Utomo \& Asyari, 1999), di samping itu hidrologi perairan rawa masih normal sehingga ikan dapat beruaya bebas sesuai dengan kebutuhan mereka (ruaya pemijahan, ruaya mencari pakan, dan ruaya pengungsian) dan tidak mengalami pendangkalan.

Musim penangkapan alat tangkap hampang juga terjadi pada saat akhir musim penghujan. Pada lokasi tertentu kegiatan penangkapan dengan hampang bisa lebih awal dari lokasi lain, hal ini tergantung dari topografi daerah, sebagai contoh di lokasi Paminggir yang perairannya lebih dangkal alat tangkap tersebut mulai beroperasi pada bulan Mei sedangkan daerah lain baru mulai bulan Juni. Hasil tangkapan hampang berkisar antara 50-250 kg per hari, hasil tangkapan yang tinggi hanya berlangsung kurang lebih 2 minggu.

Musim penangkapan dengan alat mangumpe terjadi pada saat musim kemarau. Pada lokasi tertentu yang perairannya dangkal kegiatan penangkapan dengan alat tersebut lebih awal sebagai contoh di daerah Paminggir alat mangumpe sudah beroperasi pada bulan Juni, sedangkan daerah lain baru mulai pada bulan September. Waktu penangkapan dengan alat tersebut sangat pendek, hasil tangkapan yang tinggi hanya diperoleh dalam waktu kurang lebih 1 minggu dengan hasil tangkapan berkisar antara $70-175 \mathrm{~kg}$ per hari.

Kegiatan penangkapan dengan alat tangkap beje dilakukan pada saat musim kemarau. Pada daerah tertentu seperti Paminggir yang perairannya dangkal kegiatan penangkapan lebih awal yaitu pada bulan Mei sedangkan di lokasi lain baru dimulai pada bulan Juil. Hasil tangkapan beje berkisar antara 40-200 kg per hari. Waktu penangkapan dengan alat ini sangat pendek yaitu berkisar antara 2-4 hari, setelah itu ikan dalam beje habis (lihat Tabel 2). 

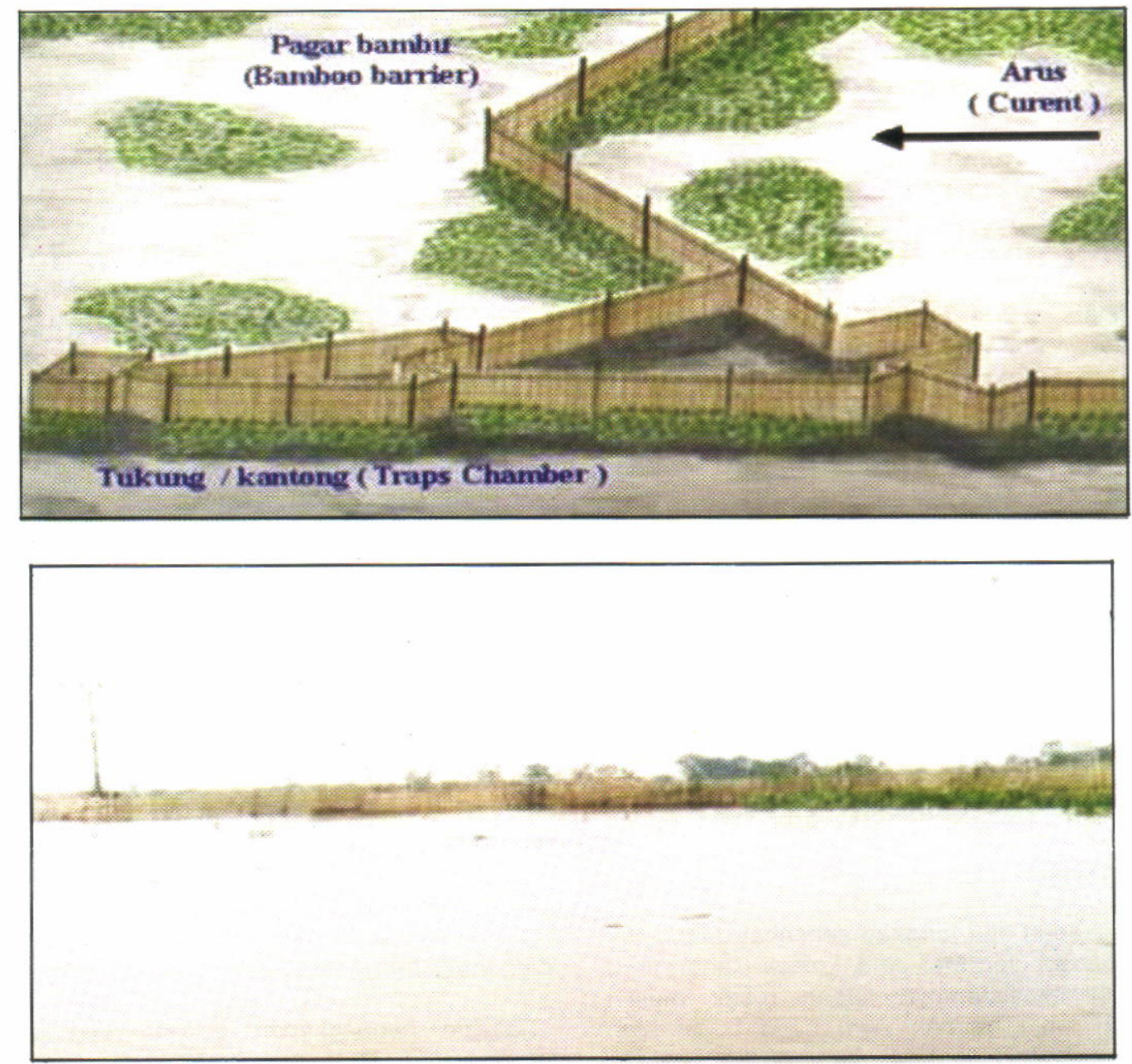

Gambar 2. Gambar dan potret hampang di Kalimantan Selatan.

Figure 2. Figue and photo of barrier traps at South Kalimantan.

\section{Komposisi Hasil Tangkapan}

Pada Tabel 3 dapat dilihat komposisi hasil tangkapan alat tangkap beje $100 \%$ merupakan kelompok ikan hitam (black fish) yang merupakan penghuni ikan rawa. Ikan tersebut mampu hidup dalam kondisi perairan yang asam dan sedikit kandungan oksigen karena ikan tersebut mempunyai alat pernapasan tambahan. Komposisi hasil tangkapan alat hampang didominansi oleh kelompok ikan hitam terutama ikan haruan, biawan, dan sepat siam. Selambau yang dioperasikan di anak sungai atau kanal di kedua lokasi yaitu Rantau Birit (ekosistem yang telah rusak) dan di Pal Batu (ekosistemnya masih baik), komposisi hasil tangkapannya berbeda. Lokasi di Rantai Birit yang hutan rawanya telah rusak berat, hasil tangkapan selambau didominansi oleh jenis ikan kecil pemakan periphyton (lumut) seperti sepat siam dan sepat bujur. Di lokasi Pal Batu yang kondisi hutan rawanya masih baik, hasil tangkapan selambau di dominansi oleh ikan berukuran besar pemakan ikan, moluska, buah atau biji bijian, dan serangga air seperti ikan tapa, tabirin, lais, dan patin.

\section{Selektivitas Alat Tangkap Terhadap Ukuran Beberapa Jenis Ikan}

\section{Alat hampang (Barrier with traps chamber)}

Pada Gambar 6 dapat dilihat bahwa ikan baung (Mystus nemurus) yang tertangkap berukuran antara $10-34 \mathrm{~cm}$. Ikan baung yang berukuran kecil mudah tertangkap karena jarak antar anyaman bambu pada alat ini hanya berkisar antara $1-2,5 \mathrm{~cm}$, bentuk kepalanya besar dan mempunyai duri keras yang panjang pada sirip dada dan duri sirip punggung sehingga sulit meloloskan diri dari alat tersebut. Ikan baung pada ukuran panjang $10 \mathrm{~cm}$ (Berat badan $15 \mathrm{~g}$ ) mempunyai tinggi badan $2 \mathrm{~cm}$, duri keras sirip 

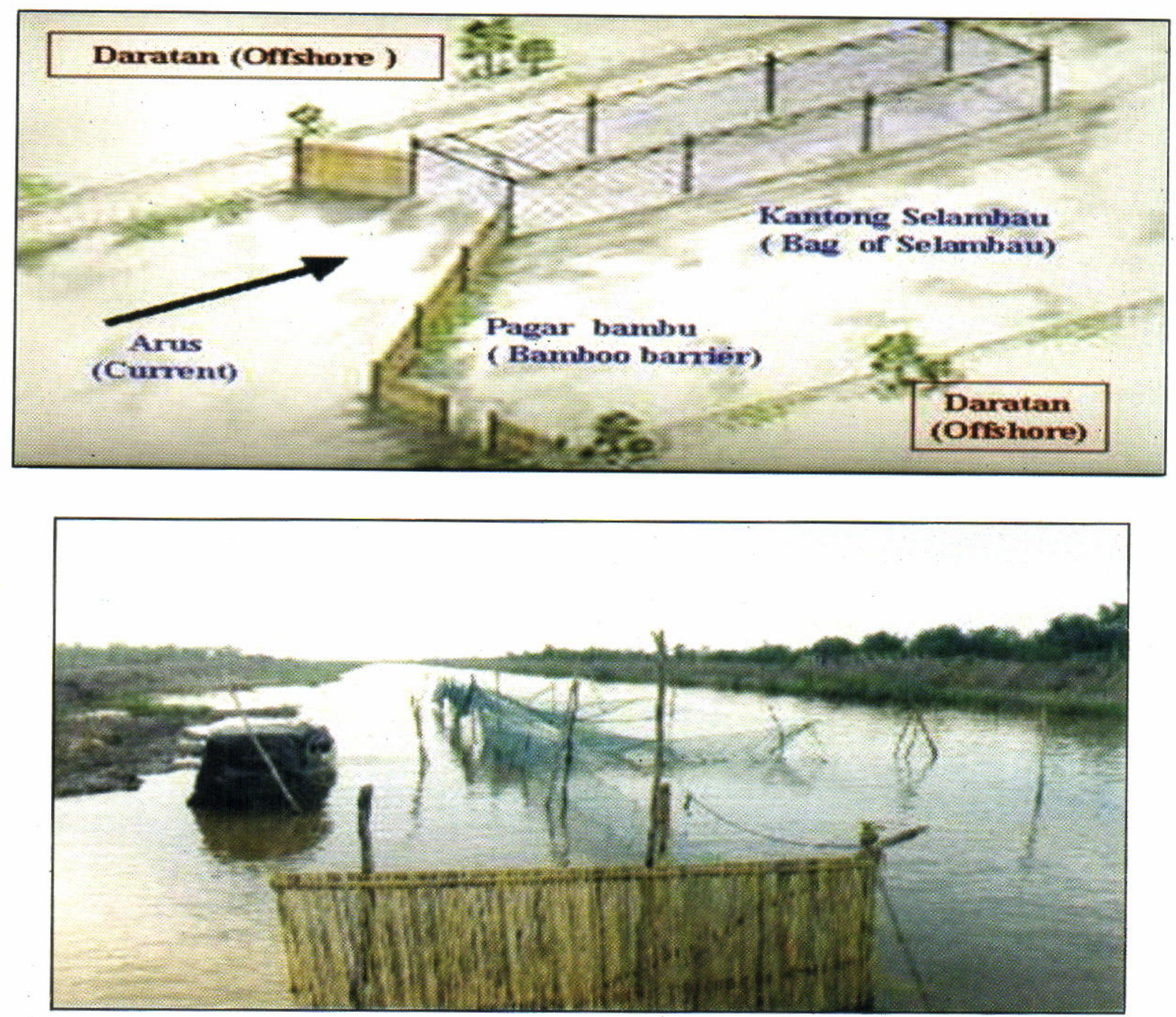

Gambar 3. Figure 3. Gambar dan potret alat tangkap selambau di Kalimantan Tengah. Figure and Photo of filtering net at Centre Kalimantan.

punggung $1 \mathrm{~cm}$, dan duri keras sirip dada $1,25 \mathrm{~cm}$. Berdasarkan pada pengamatan di lapangan ikan baung dapat matang gonad setelah berukuran $20 \mathrm{~cm}$ (berat badan $110 \mathrm{~g}$ ), ikan baung di bawah $15 \mathrm{~cm}$ (berat badan $40 \mathrm{~g}$ ) kurang bernilai ekonomis. Seyogyanya ikan baung boleh ditangkap setelah berukuran $20 \mathrm{~cm}$ (tinggi badan $4 \mathrm{~cm}$ ), ukuran tersebut sudah dapat bereproduksi sehingga dapat memberi kesempatan untuk berkembang biak sebelum ditangkap dan pada ukuran tersebut bernilai ekonomis lebih baik.

Ikan haruan (Channa striata) yang tertangkap oleh alat hampang berukuran antara $6-41 \mathrm{~cm}$. Penyebab ikan haruan mudah tertangkap oleh alat hampang karena jarak anyaman antar bambu hanya $1-2,5 \mathrm{~cm}$ dan ukuran diameter badan ikan haruan relatif besar sehingga tidak dapat meloloskan diri dari alat tersebut. Berdasarkan pada pengamatan di lapangan ikan haruan pada ukuran panjang $13 \mathrm{~cm}$ (berat badan
$35 \mathrm{~g}$ dan tinggi badan $1,8 \mathrm{~cm}$ ) mulai banyak tertangkap. Ikan haruan dapat matang gonad setelah berukuran $18 \mathrm{~cm}$, sedangkan ukuran nilai ekonomis di pasaran mulai di atas $17 \mathrm{~cm}$ (Makmur, 2003; Kartamihardja, 1994). Seyogyanya ikan haruan boleh ditangkap setelah berukuran lebih dari $18 \mathrm{~cm}$ (berat badan $80 \mathrm{~g}$ dan lebar badan $2,5 \mathrm{~cm}$ ) untuk memberi kesempatan untuk melakukan reproduksi terlebih dulu sebelum tertangkap.

Ikan sepat siam (Trichogaster pectoralis) yang tertangkap oleh alat hampang berukuran antara 13$18 \mathrm{~cm}$. Sepat siam dapat matang gonad pada ukuran $12-13 \mathrm{~cm}$ (berat badan 25-30 g) dan sudah mempunyai nilai ekonomis di pasaran (Utomo \& Ondara, 1987). Ikan sepat siam di bawah $12 \mathrm{~cm}$ jarang tertangkap oleh alat hampang hal ini disebabkan ikan sepat siam bentuk badannya pipih, pada ukuran panjang $12 \mathrm{~cm}$ tebal badannya hanya $1,5 \mathrm{~cm}$, duri sirip keras tidak tidak panjang sehingga 

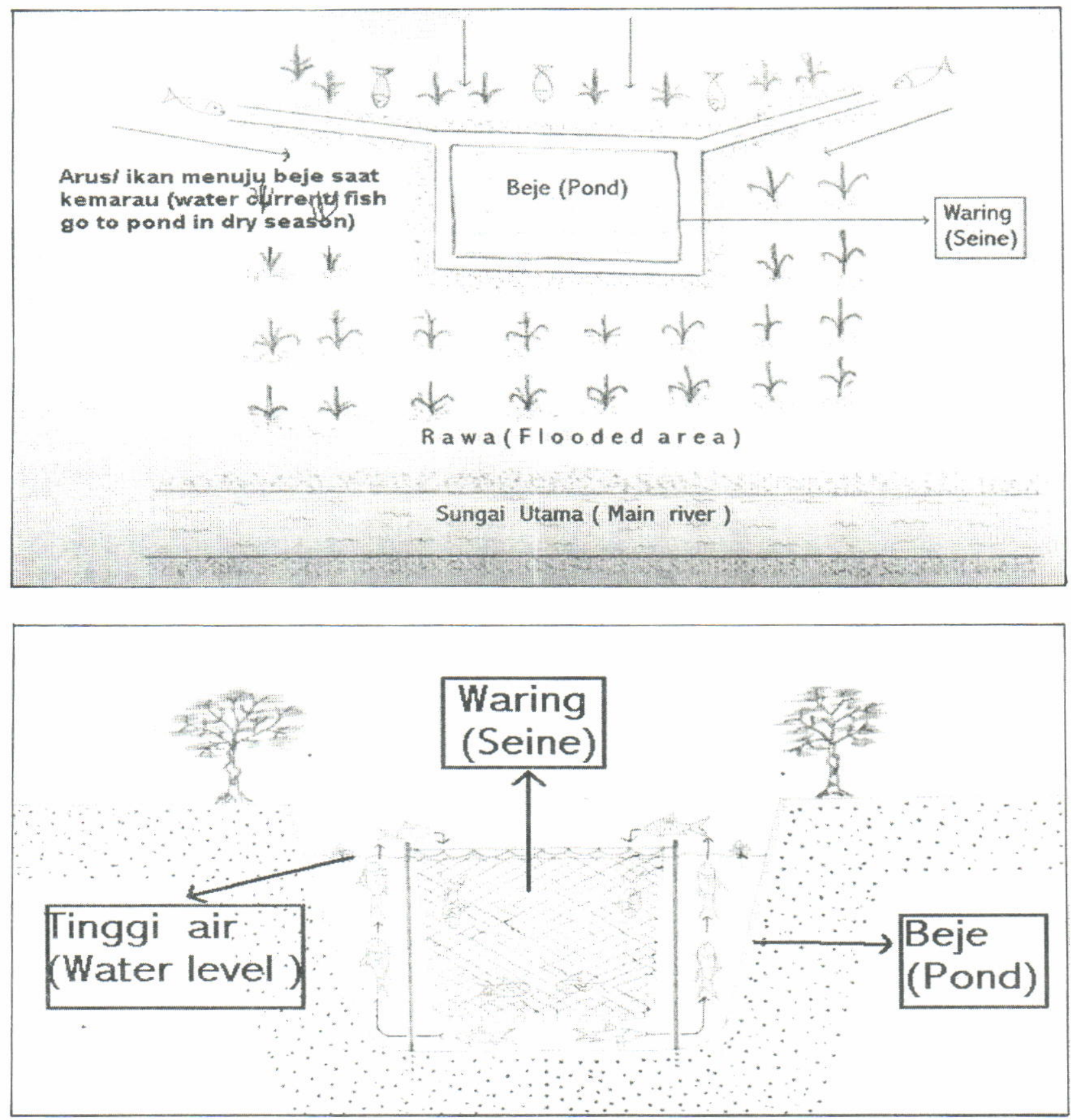

Gambar 4. Gambar mendatar dan penampang melintang alat tangkap beje.

Figure 4. Figure of horizontal and cross section of seine on pond traps.

mudah meloloskan diri dari alat tersebut. Berdasarkan pada pengamatan di lapangan ikan sepat siam yang tertangkap hampang sudah dewasa, sudah sempat berkembang biak sebelum tertangkap.

Alat tangkap beje (Seine with pond traps)

Pada Gambar 7 dapat dilihat bahwa ikan haruan (Channa striata) yang tertangkap oleh alat beje berkisar antara $14-40 \mathrm{~cm}$, sedangkan ukuran yang kecil yaitu panjang di bawah $14 \mathrm{~cm}$ elengan diameter badan $1,9 \mathrm{~cm}$ jarang tertangkap. Hal tersebut, disebabkan karena ukuran mata jaring (mesh size) nilon yang digunakan berukuran $1,5-2 \mathrm{~cm}$ sedangkan bentuk kepala dan badan ikan haruan bulat atau silindris, bentuk badan memanjang, dan duri sirip keras di dada maupun di punggung tidak panjang sehingga mudah lolos melalui mata jaring. Seyogyanya ikan gabus boleh ditangkap setelah berukuran lebih dari $18 \mathrm{~cm}$ (berat badan $80 \mathrm{~g}$ dan 


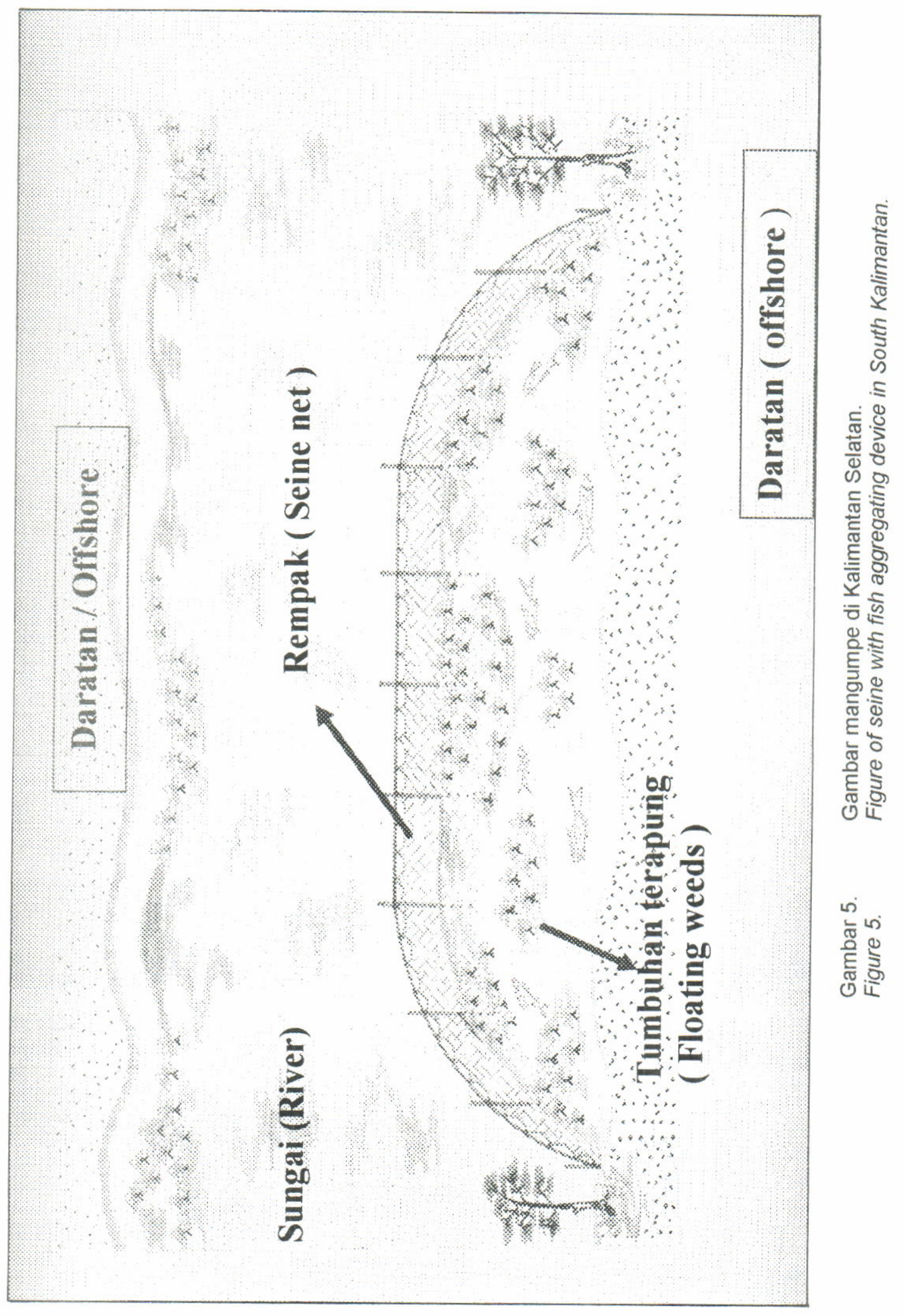


Tabel 2. Hasil tangkapan ikan dari beberapa macam alat tangkap dan lokasi

Table 2. Catches of some fishing gears and location

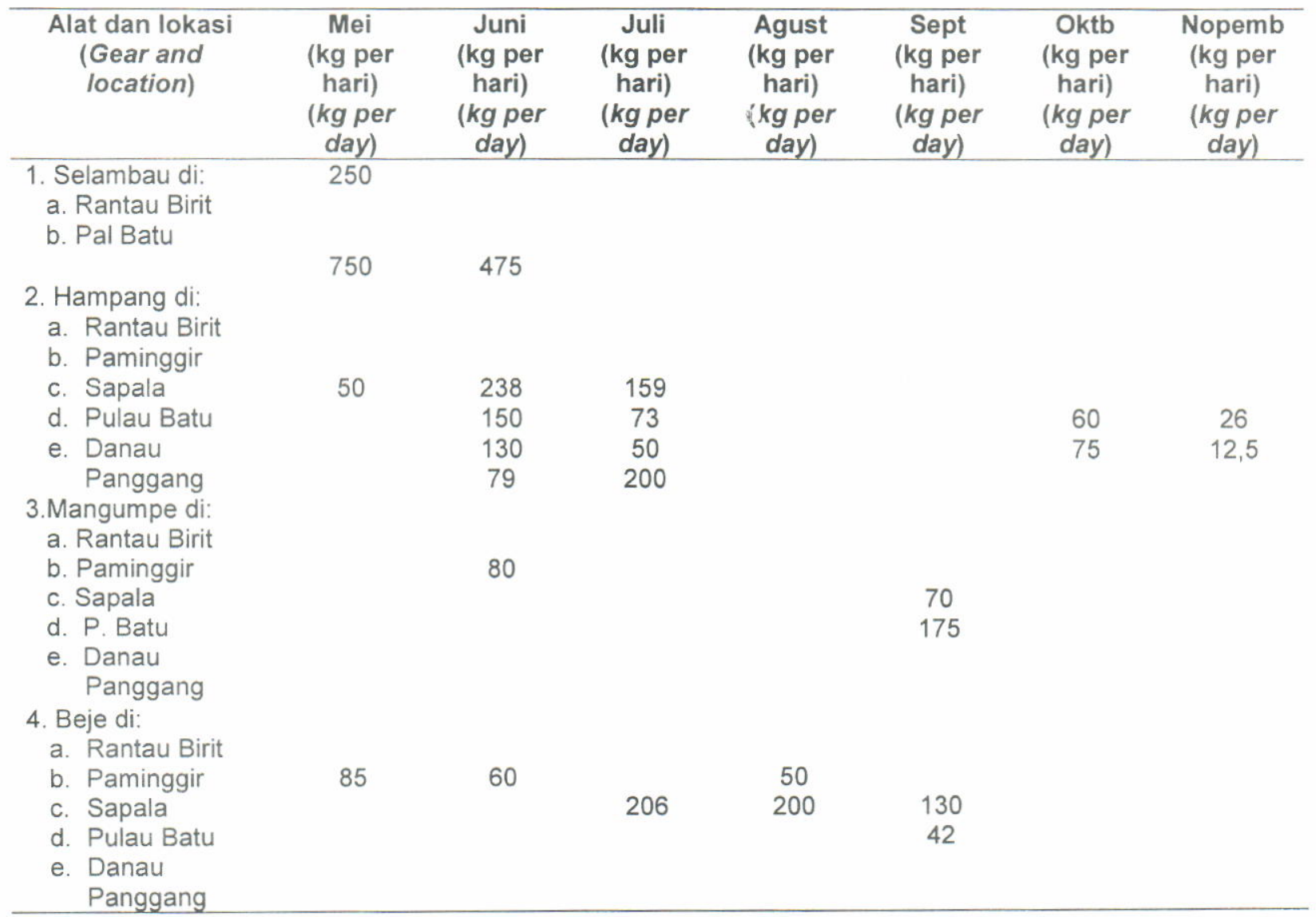

lebar badan badan $2,5 \mathrm{~cm}$ ) untuk memberi kesempatan untuk berkembang biak sebelum ditangkap.

Ikan papuyu (Anabas testudineus) yang tertangkap oleh alat tangkap beje berukuran antara $8-20 \mathrm{~cm}$. Berdasarkan pada pengamatan di lapangan ikan papuyuh dapat matang gonad pada ukuran diatas 11$12 \mathrm{~cm}$ dengan berat $30-40 \mathrm{~g}$, sedangkan yang berukuran $8 \mathrm{~cm}$ beratnya hanya $15 \mathrm{~g}$ dan tidak bernilai ekonomis di pasaran. Seyogyanya penangkapan ikan papuyu dilakukan setelah berukuran di atas $11 \mathrm{~cm}$ untuk memberi kesempatan melakukan reproduksi dan pada ukuran di atas $12 \mathrm{~cm}$ sudah bernilai ekonomis di pasaran. Ikan papuyu yang kecil mudah tertangkap oleh beje disebabkan karena ukuran mata jaring nilon hanya 1,5-2 cm, ikan papuyu mempunyai banyak duri sirip yang keras yang panjang di punggung, mempunyai tulang insang berduri yang menonjol ke luar yang sering menyangkut di mata jaring. Pada ukuran panjang 8$10 \mathrm{~cm}$ mempunyai tinggi badan $2-2,5 \mathrm{~cm}$ dan tebal badan $1,2-1,5 \mathrm{~cm}$.

Ikan sepat siam yang tertangkap oleh beje ukurannya 11-16 cm, sebaiknya ikan sepat siam yang tertangkap setelah berukuran $12 \mathrm{~cm}$ (berat badan 35 g) untuk memberi kesempatan berkembang biak dan sudah bernilai ekonomis.

\section{Alat tangkap selambau (Filtering net)}

Pada Gambar 8 terlihat bahwa ikan sepat siam yang tertangkap berukuran antara 9-15 cm. Kegiatan penangkapan dengan alat selambau kurang dapat memberi kesempatan ikan sepat siam yang berukuran kecil untuk melakukan reproduksi karena ukuran di bawah $12 \mathrm{~cm}$ sudah banyak yang tertangkap, di samping itu ukuran di bawah $10 \mathrm{~cm}$ (berat badan 15 g) tidak bernilai ekonomis di pasaran. Jenis ikan sepat yang lain yang sering tertangkap dengan alat selambau yaitu sepat bujur (Trichogaster sp.), tertangkap dengan alat selambau berukuran antara 5$9 \mathrm{~cm}$, hal tersebut menunjukkan bahwa selambau termasuk alat tangkap yang tidak selektif terhadap ukuran. Berdasarkan pada pengamatan di lapangan sepat bujur dapat matang gonad dan bereproduksi pada ukuran di atas $8 \mathrm{~cm}$, seyogyanya ikan tersebut ditangkap setelah ukuran $8 \mathrm{~cm}$ untuk memberi kesempatan ikan tersebut berkembang biak terlebih dahulu.

Untuk kelestarian sumber daya ikan, maka ikan berukuran kecil yang tertangkap seperti ikan baung di bawah $20 \mathrm{~cm}$, ikan haruan di bawah $18 \mathrm{~cm}$, ikan 
Tabel 3. Komposisi hasil tangkapan ikan dari beberapa alat tangkap

Table 3. Catch composision of some fishing gears

\begin{tabular}{|c|c|c|c|c|c|}
\hline $\begin{array}{l}\text { Jenis ikan dan panjang } \\
\text { (Species and length) } \\
\text { (cm) }\end{array}$ & $\begin{array}{c}\text { Hampang } \\
\text { (Barrier } \\
\text { with traps } \\
\text { chamber) } \\
(\%)\end{array}$ & $\begin{array}{c}\text { Selambau di } \\
\text { Rantau Birit } \\
\text { (Filtering } \\
\text { net) } \\
(\%)\end{array}$ & $\begin{array}{c}\text { Selambau di } \\
\text { P. Batu } \\
\text { (Filtering net) } \\
\text { (\%) }\end{array}$ & $\begin{array}{l}\text { Mangumpe } \\
\text { (Seine with } \\
\text { fish } \\
\text { aggregating } \\
\text { device) } \\
(\%) \\
\end{array}$ & $\begin{array}{c}\text { Beje } \\
\text { (Seine } \\
\text { with pond } \\
\text { traps) } \\
(\%)\end{array}$ \\
\hline $\begin{array}{l}\text { 1. Sepat siam (13-19) } \\
\text { (Trichogaster pectoralis) }\end{array}$ & 25,5 & 35,5 & & 6,7 & 15,4 \\
\hline $\begin{array}{l}\text { 2. Sepat bujur }(5-10) \\
\text { (Trichogaster tricopterus) }\end{array}$ & & 12,4 & & 9 & 30,7 \\
\hline $\begin{array}{l}\text { 3. Papuyuh (8-17) } \\
\text { (Anabas tesudineus) }\end{array}$ & 1,7 & 15,9 & & 4,4 & 23 \\
\hline $\begin{array}{l}\text { 4. Haruan }(15-45) \\
\text { (Channa striata) }\end{array}$ & 38,6 & 7,1 & & 6,7 & 19 \\
\hline $\begin{array}{l}\text { 5. Biawan (12-20) } \\
\text { (Helostoma temminckii) }\end{array}$ & 25,5 & 1,8 & & & 11,9 \\
\hline $\begin{array}{l}\text { 6. Riu (6-11) } \\
\text { (Pseudeutropius sp.) }\end{array}$ & & 5,3 & & & \\
\hline $\begin{array}{l}\text { 7. Kepor (9-13) } \\
\text { (Pristolepis fasciata) }\end{array}$ & & 0,35 & & & \\
\hline $\begin{array}{l}\text { 8. Seluang (3-7) } \\
\text { (Rasbora sp.) }\end{array}$ & & 0,7 & & & \\
\hline $\begin{array}{l}\text { 9. Lawang ( } 30-45) \\
\text { (Pangasius polyurounodon) }\end{array}$ & & 3,55 & & & \\
\hline $\begin{array}{l}\text { 10. Sanggiringan (10-13) } \\
\text { (Mystus nigriceps) }\end{array}$ & 4 & 5,3 & & & \\
\hline $\begin{array}{l}\text { 11. Baung (15-50) } \\
\text { (Mystus nemurus) }\end{array}$ & & 0,35 & 7,3 & 5,6 & \\
\hline $\begin{array}{l}\text { 12. Lais }(10-30) \\
\text { (Kryptopterus sp.) }\end{array}$ & 4,7 & 1,06 & 5,6 & 67,6 & \\
\hline $\begin{array}{l}\text { 13. Sanggang (20-30) } \\
\text { (Puntioplites bulu) } \\
\text { 14. Tapa }(80-110)\end{array}$ & & & 8 & & \\
\hline $\begin{array}{r}\text { (Wallago leeri) } \\
\text { 15. Patin }(35-65)\end{array}$ & & & 44 & & \\
\hline $\begin{array}{l}\text { (Pangasius spp.) } \\
\text { 16. Tabirin (35-50) }\end{array}$ & & & 10,2 & & \\
\hline $\begin{array}{l}\text { 17. Lain } \\
\text { Wallago dinema) }\end{array}$ & & 10.55 & 24,6 & & \\
\hline Jumlah & 100 & 100 & 100 & 100 & 100 \\
\hline
\end{tabular}

papuyu di bawah $11 \mathrm{~cm}$, dan ikan sepat siam di bawah $12 \mathrm{~cm}$ agar dilepas kembali ke perairan untuk memberi kesempatan ikan tersebut dapat berkembang biak terlebih dahulu. Ikan yang baru tertangkap oleh akat tangkap beje, hampang, dan selambau kondisimya masih baik, sehingga apabila dilepas ke perairan kembali masih dapat hidup. Apabila dilakukan kebijakan untuk memperbesar ukuran mata jaring atau jarak anyaman maka kemungkinan akan merugikan nelayan karena jenis ikan kecil seperti ikan seluang, riu, beberapa jenis ikan lais, sepat bujur tidak akan tertangkap.

\section{Pertumbuhan dan Mortalitas}

Berdasarkan pada analisis frekuensi ukuran ikan (length frequency data) dari bulan ke bulan (Tabel 4, 5, dan 6) dengan bantuan paket program FISAT II (untuk pertumbuhan lihat Gambar 9-11), untuk mortalitas lihat Gambar 12-13) didapatkan parameter pertumbuhan Vont Bertalanfy ( $K$ dan $L \infty$ ) dan parameter mortalitas alami (M), mortalitas penangkapan (F) dan mortalitas total $(Z)$, serta laju penangkapan (E) untuk masing-masing jenis ikan (lihat Tabel 7). 

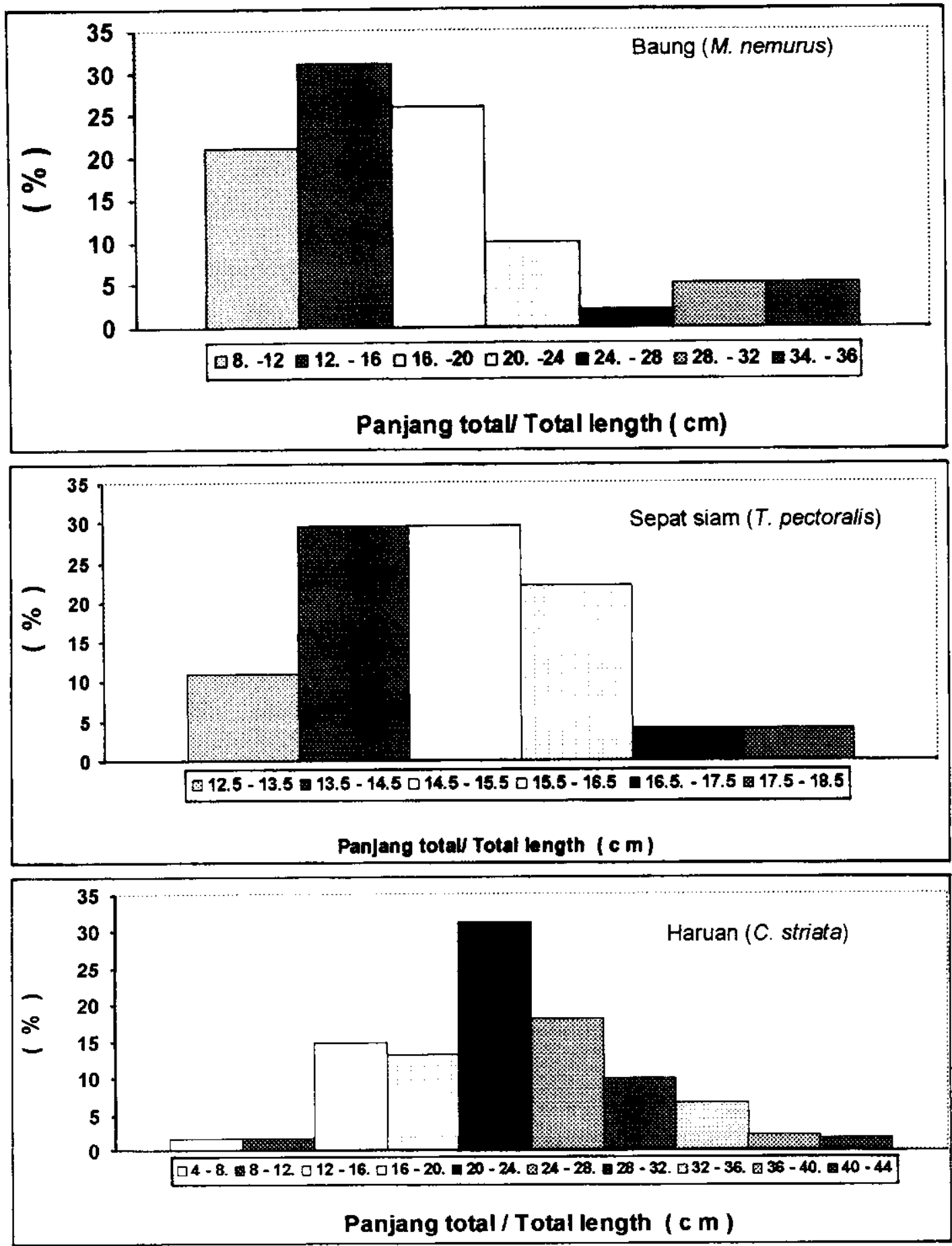

Gambar 6. Selektivitas alat tangkap hampang terhadap ukuran beberapa jenis ikan.

Figure 6. Barrier traps selectivity on length of some fishes.

Ikan gabus dan ikan baung merupakan contoh ikan yang berukuran relatif besar. Ikan gabus hidup di rawa (black fish) dan baung di sungai (white fish). Laju penangkapan (E) kedua jenis ikan tersebut sudah tidak dapat ditingkatkan lagi karena sudah lebih besar dari nilai optimum 0,5 (Gulland, dalam Pauly, 1984) yaitu $E=0,57$ untuk ikan haruan dan $E=0,71$ untuk ikan baung. Sedangkan sepat siam merupakan contoh ikan berukuran kecil di perairan rawa, tingkat laju penangkapan (E) masih dapat ditingkatkan karena nilainya masih di bawah 0,5 yaitu $E=0,41$ (lihat Tabel 4).

Ikan yang berukuran besar cenderung tidak akan lolos dari alat tangkap, ikan baung, dan gabus mempunyai ukuran kepala yang besar, apalagi ikan baung mempunyai duri sirip di dada dan punggung yang akan tersangkut di alat tangkap, sedangkan ikan 

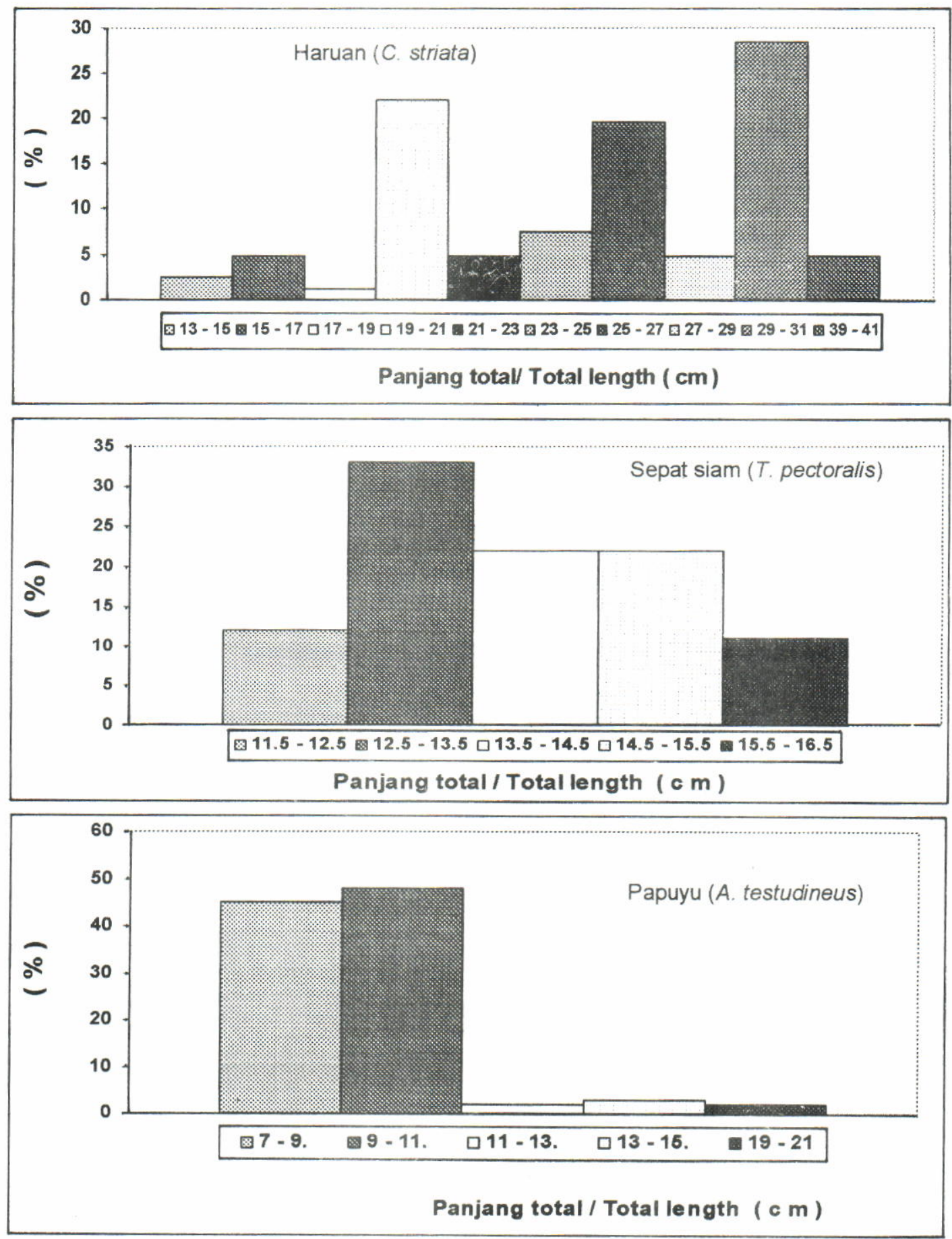

Gambar 7. Figure 7. Selektivitas alat tangkap beje terhadap ukuran beberapa jenis ikan. Seine selevtivity on length of some fishes at pond traps.

berukuran kecil akan banyak lolos dari alat tangkap, apalagi ikan sepat siam yang bentuknya pipih mudah lolos dari alat tangkap hampang yang banyak beroperasi di perairan rawa banjiran, selain itu ikan berukuran kecil seperti sepat siam mempunyai tingkat reproduksi yang lebih tinggi daripada ikan yang berukuran besar. Ikan sepat siam merupakan jenis ikan yang dominan di perairan rawa, tahan terhadap perairan asam dan oksigen relatif rendah, cepat berkembang biak, dalam 1 tahun melakukan pemijahan 2-3 kali, fekunditasnya tinggi yaitu 30.000 40.000 butir telur per ekor, sehingga populasi di alam banyak walaupun banyak ditangkap.

Hoggarth \& Utomo, (1994) menyatakan bahwa ikan baung merupakan ikan yang beruaya jarak sedang. Jenis ikan yang beruaya lebih mudah tertangkap terutama dengan jenis alat perangkap 

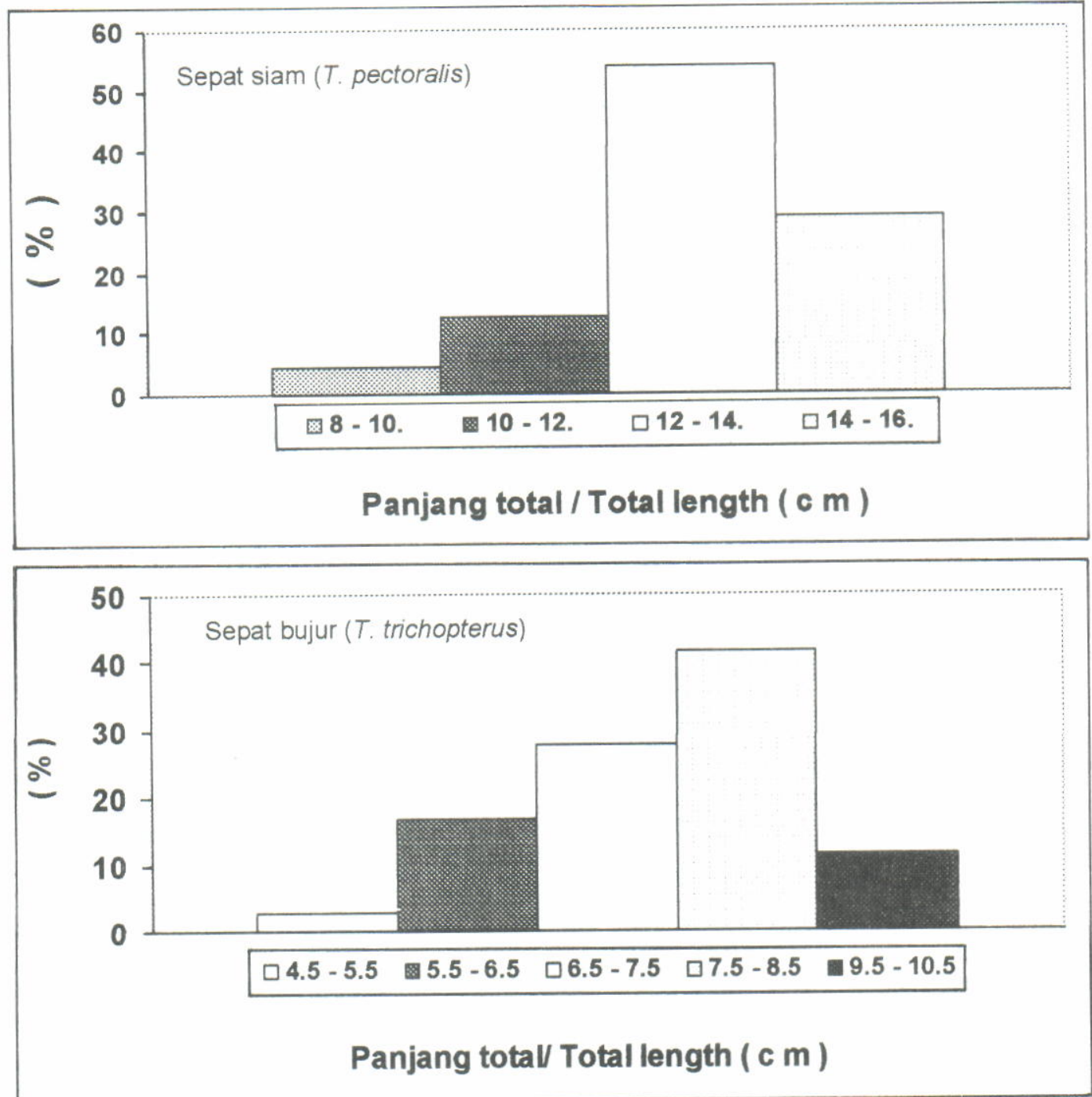

Gambar 8. Selektivitas alat tangkap selambau terhadap ukuran beberapa jenis ikan.

Figure 8. Filtering net selectivity on length of some fishes.

Tabel 4. Frekuensi ukuran panjang ikan sepat siam (T. pectoralis)

Table 4. Length frequency of sepat siam (T. pectoralis)

\begin{tabular}{|c|c|c|c|c|c|c|}
\hline \multirow{2}{*}{$\begin{array}{l}\text { Nilai tengah } \\
\text { (Mid length) } \\
(\mathrm{cm})\end{array}$} & \multicolumn{6}{|c|}{ Jumlah ekor (number) } \\
\hline & Juni & Juli & Agustus & September & Oktober & Nopember \\
\hline 9 & 4 & & & & & \\
\hline 10 & & & & & & \\
\hline $\begin{array}{l}12 \\
13\end{array}$ & $\begin{array}{l}8 \\
8\end{array}$ & & $\begin{array}{l}12 \\
31\end{array}$ & 2 & & \\
\hline 14 & $\begin{array}{c}8 \\
32\end{array}$ & & $\begin{array}{l}31 \\
25\end{array}$ & $\begin{array}{c}2 \\
14\end{array}$ & & 14 \\
\hline 15 & 32 & & 15 & 22 & & 22 \\
\hline 16 & 16 & & 8 & 22 & & 22 \\
\hline 17 & & & 9 & 24 & & 26 \\
\hline 18 & & & & 13 & & 14 \\
\hline
\end{tabular}

(traps), sehingga mortalitas penangkapannya relatif tinggi. Jenis alat tangkap perangkap yang berukuran besar di Sungai Musi antara lain empang (di Sungai Barito namanya hampang), tuguk, kilung (di Sungai
Barito namanya selambau). Selanjutnya, Utomo et al. (1994) menyatakan bahwa nilai laju penangkapn ikan baung di Sungai Batanghari Jambi juga sudah cukup tinggi yaitu $E=0,64$. 
Tabel 5. Frekuensi ukuran panjang ikan haruan (C. striatus)

Table 5. Length frequency of haruan (C. striatus)

\begin{tabular}{|c|c|c|c|c|c|c|c|}
\hline \multirow{2}{*}{$\begin{array}{l}\text { Nilai tengah } \\
\text { (Mid length) } \\
\text { (cm) }\end{array}$} & \multicolumn{7}{|c|}{ Jumlah ekor (number) } \\
\hline & Mei & Juni & Juli & Agustus & September & Oktober & Nopember \\
\hline 7 & 251 & & & & & & \\
\hline 9 & & & & & & 4 & \\
\hline 11 & & & & & & & \\
\hline 13 & & & & & & & 20 \\
\hline 15 & & & & & & 42 & 44 \\
\hline 17 & & & & & 61 & 3 & 45 \\
\hline 19 & & & & & 199 & 59 & 31 \\
\hline 21 & & & & & 23 & 8 & \\
\hline 23 & & & & & & 10 & 57 \\
\hline 25 & & & & & 170 & 10 & \\
\hline 27 & & & & & 53 & 6 & \\
\hline 29 & & & & & 255 & 5 & \\
\hline 31 & 40 & & & & & 36 & \\
\hline 33 & 173 & & & & & 20 & 10 \\
\hline 25 & 52 & & & & & & \\
\hline 37 & & & & & & & \\
\hline 39 & 183 & & & & & & \\
\hline 41 & 38 & & & & & & \\
\hline
\end{tabular}

Tabel 6. $\quad$ Frekuensi ukuran panjang ikan baung ( $M$. nemurus)

Table 6. Length frequency of baung (M. nemurus)

\begin{tabular}{|c|c|c|c|c|c|c|}
\hline \multirow{2}{*}{$\begin{array}{l}\text { Nilai tengah } \\
\text { (Mid length) } \\
\text { (cm) }\end{array}$} & \multicolumn{6}{|c|}{ Jumlah ekor (number) } \\
\hline & Juni & Juli & Agustus & September & Oktober & Nopember \\
\hline 27 & 7 & & & & & \\
\hline 29 & 5 & & & & 20 & \\
\hline 31 & 8 & & & & & \\
\hline 33 & 8 & & & & & \\
\hline 35 & & & 24 & & 30 & \\
\hline 37 & & & & & & \\
\hline 39 & & & 75 & & 30 & \\
\hline 41 & & & & & 25 & \\
\hline 43 & & & & & & \\
\hline 45 & & & & & 10 & \\
\hline
\end{tabular}




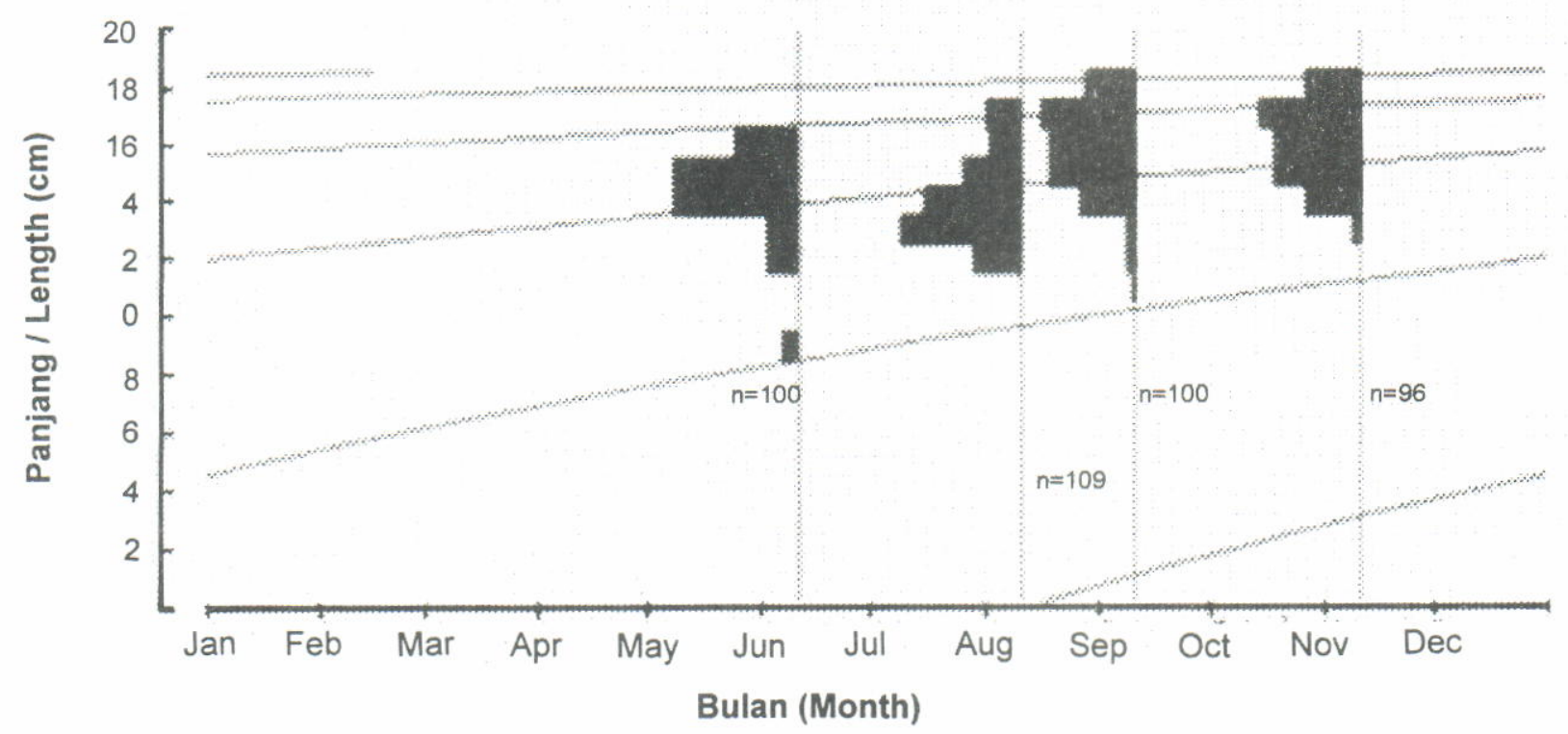

Gambar 9. Kurva pertumbuhan Von Bertalanffy terhadap frekuensi panjang total ikan sepat siam ( $T$. Figure 9. $\quad$ Curve of Von Bertalanffy growth on total length frequency of sepat siam (T. pectoralis).

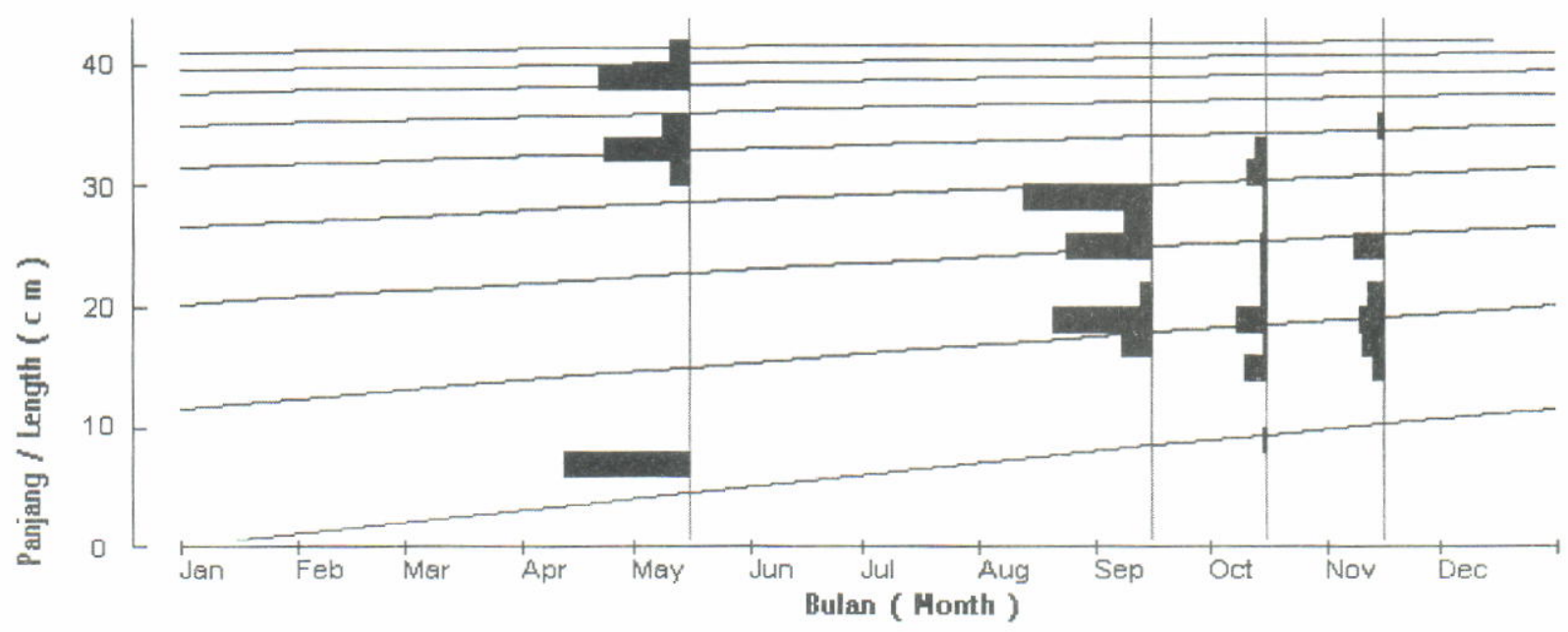

Gambar 10. Kurva pertumbuhan Von Bertalanffy terhadap frekuensi panjang total ikan haruan (C. striata). Figure 10. Curve of Von Bertalanffy growth on total length frequency of sepat siam (C. striata). 


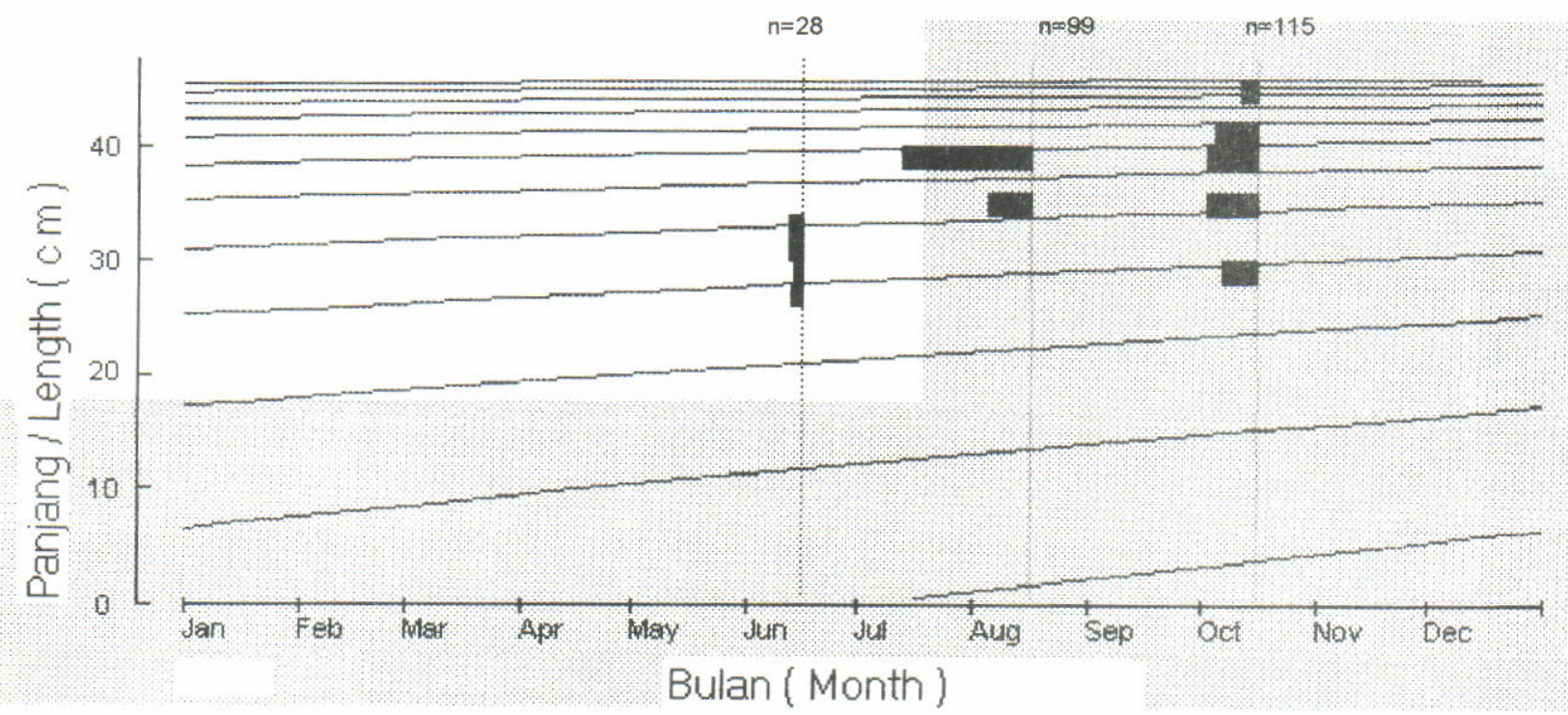

Gambar 11. Kurva pertumbuhan Von Bertalanffy terhadap frekuensi panjang total ikan baung (M. nemurus) Figure 11. Curve of Von Bertalanffy growth on total length frequency of baung (M. nemurus).
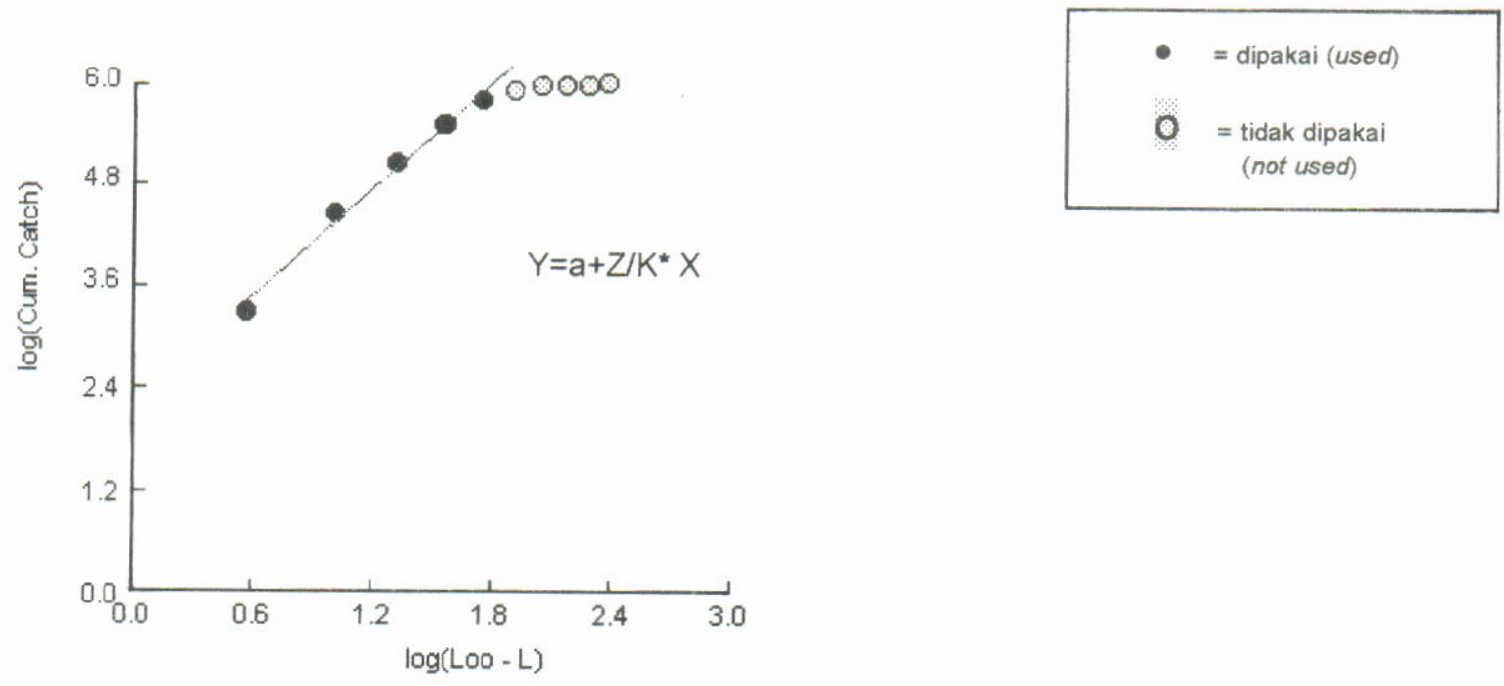

Gambar 12. Analisis parameter mortalitas ikan sepat siam (T. pectoralis).

Figure 12. Mortality parameter analisys of sepat siam (T. pectoralis). 


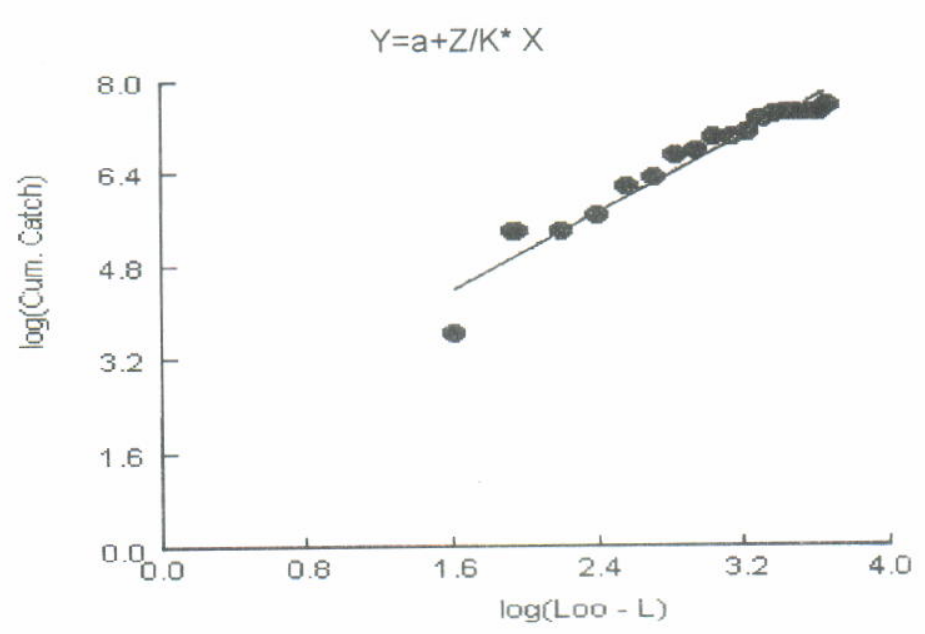

- = dipakai (used)

- tidak dipakai (not used)

Gambar 13. Analisis parameter mortalitas ikan haruan (C. striatus).

Figure 13. Analisis of mortality parameter of haruan (C. striatus).

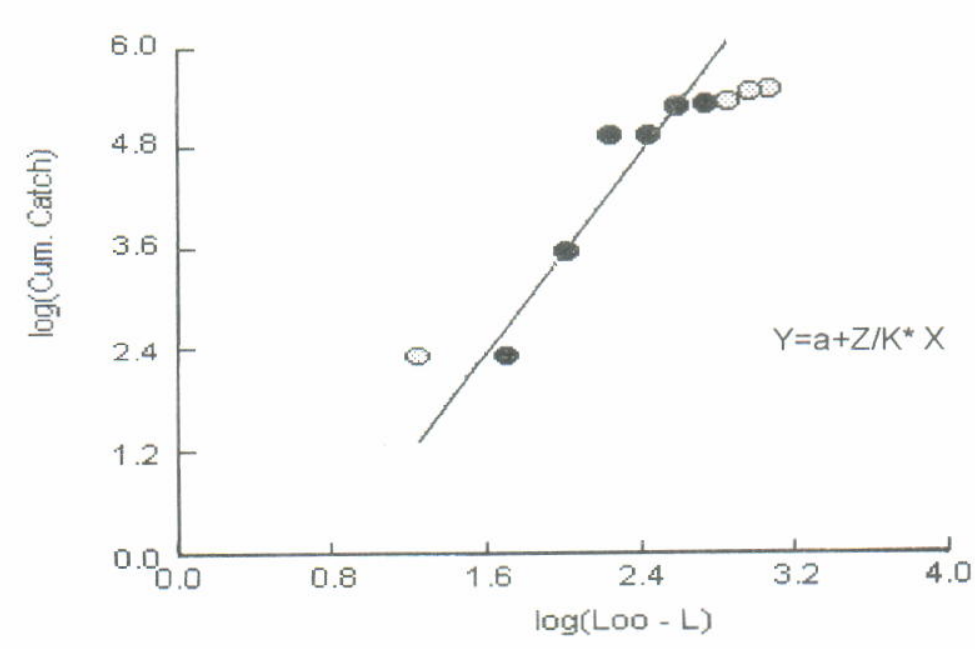

- = dipakai (used)

- = tidak dipakai (not used)

Gambar 14. Analisis parameter mortalitas ikan baung ( $M$. nemurus).

Figure 14. Mortality parameter analisys of baung (M. nemurus).

Tabel 7. Parameter pertumbuhan dan mortalitas beberapa jenis ikan

Table 7. Growth and mortality parameters of some fishes

\begin{tabular}{|c|c|c|c|c|c|c|}
\hline \multirow[t]{2}{*}{ Jenis ikan (Species) } & \multicolumn{2}{|c|}{$\begin{array}{l}\text { Parameter pertumbuhan } \\
\text { (Growth parameter) }\end{array}$} & \multicolumn{4}{|c|}{$\begin{array}{l}\text { Parameter mortalitas } \\
\text { (Mortality parameter) }\end{array}$} \\
\hline & $\mathrm{L}_{\infty}(\mathrm{cm})$ & $\mathrm{K}$ & Z & $M$ & $\mathrm{~F}$ & $E$ \\
\hline Sepat siam ( $T$. pectoralis) & 19,75 & 0,6 & 2,44 & 1,43 & 1,01 & 0,41 \\
\hline Baung ( $M$. nemurus) & 47,50 & 0,4 & 2,96 & 0,86 & 2,10 & 0,71 \\
\hline Gabus (C. striatus) & 45 & 0,3 & 1,70 & 0,72 & 0,98 & 0,57 \\
\hline
\end{tabular}




\section{KESIMPULAN DAN SARAN}

\section{Kesimpulan}

1. Di Rantau Birit (Kalimantan Tengah) dengan ekosistemnya yang telah rusak hasil tangkapan ikan lebih rendah dibanding di Pal Batu (Kalimantan Selatan) yang ekosistem perairannya masih baik.

2. Alat tangkap hampang, selambau, dan beje merupakan alat tangkap yang tidak selektif terhadap jenis ikan berukuran besar, karena ikan umur muda yang belum sempat bereproduksi sudah tertangkap.

3. Nilai laju penangkapan ikan berukuran besar seperti baung dan haruan cukup tinggi yaitu $E=0,57$ untuk haruan dan $E=0,71$ untuk ikan baung, sedangkan ikan berukuran kecil seperti sepat siam masih rendah yaitu $E=0,41$.

\section{Saran}

Ikan umur muda berukuran kecil yang tertangkap seperti ikan baung di bawah $20 \mathrm{~cm}$, ikan haruan di bawah $18 \mathrm{~cm}$, ikan papuyu di bawah $11 \mathrm{~cm}$, dan ikan sepat siam di bawah $12 \mathrm{~cm}$ agar dilepas kembali ke perairan untuk memberi kesempatan ikan tersebut dapat berkembang biak terlebih dahulu. Ikan yang baru tertangkap oleh akat tangkap beje, hampang, dan selambau kondisimya masih baik, sehingga apabila dilepas ke perairan kembali masih dapat hidup.

\section{UCAPAN TERIMA KASIH}

Penulis mengucapkan terima kasih kepada Dinas Perikanan dan Kelautan Tingkat I Kalimantan Selatan, Dinas Perikanan dan Kelautan Tingkat II Kabupaten Barito Hulu, Pemerintah Desa beserta masyarakat nelayan di sepanjang DAS Barito yang telah banyak membantu dalam perizinan, pencatatan hasil, dan pemberian informasi yang berkaitan dengan kelancaran pelaksanaan penelitian.

\section{DAFTAR PUSTAKA}

Arifin, Z. 1978. Beberapa aspek tentang penangkapan ikan di perairan lubuk lampam Sumatera Selatan. Disampaikan dalam Simposium Modernisasi Perikanan Rakyat di Jakarta tanggal 27-30 Juni 1978. LPPD Cabang Palembang. 25 hal.

Brandt, A. V. 1972. Fish catching methods of the world. Fishing New (Books) Ltd. 110 Fleet Street, London. EC 4. pp: 204-214

Gayanilo, Jr., P. Sparre, \& D. Pauly. 1996. The FAOICLARM, Fish Stock Assessment Tools (FISAT) II
User's Guide. FAO Computerized Information Series (Fisherises). FAO, Rome (8). 126 p.

Hoggarth, D. D. \& A. D. Utomo. 1994. The fishes ecology of the lubuk lampam river flood plain in South Sumatera, Indonesia. Fisheries Research International Journal. Elsevier. Netherland: 20:191213.

Kartamihardja, E. S. 1994. Biologi popupasi ikan Gabus (Channa striata) di Waduk Kedung Ombo. Buletin Penelitian Perikanan Darat 12 (2): 113-129.

Makmur, S. 2003. Biologi reproduksi, makanan, dan pertumbuhan ikan gabus (Channa striatus) di rawa banjiran Sungai Musi Sumatera Selatan. Program Studi limu Perairan, Pascasarjana Institut Pertanian Bogor. Bogor. Tesis: 60 hal.

Pauly, D. 1984. some simple methods for the assessment of tropical fish stock. ICLARM. Makati, Metro manila-Philiphines. 52 p.

Sparre, P. \& S. C. Venema. 1992. Introduction to tropical fish stock assessment. FAO-DANIDA. Rome. 306 (1). 375 p.

Utomo, A. D., Rupawan, \& S. Suryaningrat. 2003. Kegiatan penangkapan ikan di Sungai Barito Kalimantan Tengah dan Selatan. Prosiding Hasil Riset. Pusat Riset Perikanan Tangkap. Badan Riset Kelautan dan Perikanan. Departemen Kelautan dan Perikanan. Jakarta. Hal: 149-159.

Utomo, A. D. 2001. Ruaya udang galah (Macrobrachium rosenbergii) di Sungai Lempuing Sumatera Selatan. Program Studi IImu Perairan, Pascasarjana Institut Pertanian Bogor. Bogor. Tesis: 72 hal.

Utomo, A. D. \& Asyari. 1999. Peranan ekosistem hutan rawa air tawar bagi kelestarian sumber daya perikanan di Sungai Kapuas Kalimantan Barat. Jurnal Penelitian Perikanan Indonesia. Pusat Penelitian dan Pengembangan Perikanan. 5 (3): 114.

Utomo, A. D. \& Ondara. 1987. Pendugaan parameter pertumbuhan ikan sepat siam ( $T$. pectoralis) di perairan lubuk lampam, Sumatera Selatan. Buletin Penelitian Perikanan Darat. Bogor. 6 (1): 37-41.

Utomo, A. D., Z. Nasution, \& D. Prasetyo. 1994. Pendugaan parameter pertumbuhan, mortalitas dan laju penangkapan ikan baung (Mystus nemurus) di Sungai Batanghari Jambi. Kumpulan Makalah Seminar PPEHP Perikanan Perairan Umum. Sub Balai Penelitian Perikanan Air Tawar. Palembang. Hal: 131-135.

Welcomme, R. L. 1979. Fisheries ecology of flood plain rivers. Longman. London. pp: 106-136. 
